First publ. in: The Fungal Spore and Disease Initiation in Plants and Animals.

Ed. by G. T. Cole and C. Hoch. New York: Plenum, 1991, pp. 67-99

\title{
4 \\ Rust Basidiospore Germlings and Disease Initiation
}

\author{
Randall E. Gold and Kurt Mendgen
}

\section{INTRODUCTION}

\subsection{General}

The rust fungi are potentially dangerous plant disease organisms. Infections caused by dikaryotic urediniospores play a major role in limiting agricultural production. Consequently, research has focused on infections of this type and has been the central theme of numerous reviews (Littlefield and Heath, 1979; Bushnell and Roelfs, 1984; Mendgen et al., 1988; Hoch and Staples, this volume). Research on basidiospores and basidiospore-derived infections has received significantly less attention. This may be partially due to their lesser economic importance, but is also a result of the lack of reliable methods to activate teliospore germination, and therefore basidiospore production, of agriculturally important rusts (Petersen, 1974; Mendgen, 1984).

This chapter builds upon existing brief reviews of basidiospore germination (Petersen, 1974; Mendgen, 1984), host penetration (Littlefield and Heath, 1979), and the morphology of intracellular structures (Harder and Chong, 1984). Our approach relies on a comprehensive illustration of the events and structures important in the initiation of basidiospore-derived infections.

\subsection{Terminology}

The terminology suggested by Littlefield and Heath (1979) will be followed with the exception that intracellular infection structures, often designated as monokaryotic haustoria, will be called intracellular hyphae (Rijkenberg and Truter, 1972; Gold and Mendgen, 1984a). The extracellular, slimelike substance commonly associated with infection structures will be termed the extracellular matrix (see Gold and Mendgen, 1984b; Mims and Richardson, 1989; Nicholson and Epstein, this volume).

Randall E. Gold - BASF AG, Agricultural Research Station, D-6703 Limburgerhof, Federal Republic of Germany. Kurt Mendgen - Department of Plant Pathology, University of Constance, D-7750 Constance, Federal Republic of Germany. 


\section{BASIDIOSPORE MORPHOLOGY AND GERMINATION}

Knowledge of the morphology and germination of the rust basidiospores dates back to Gasparrini (1848) and the early accounts by Tulasne (1854), de Bary (1863, 1866), Reess (1865. 1870), and Sappin-Trouffy (1896). Basidiospores, also called sporidia in the earlier literature, are the only spore type in the rust life cycle that does not form after a preliminary infection event. Instead, they generally arise after the germination of diploid teliospores or, less commonly, in endocyclic species, after germination of aecioid teliospores (Petersen, 1974). The metabasidium generally gives rise to four, sometimes two, basidiospores on sterigmata (Figs. 1-3).

\subsection{Morphology}

\subsubsection{Macroscopic}

Masses of fresh basidiospores range from yellow to red (Reed and Crabill, 1915; Snow and Froelich, 1968) due to the presence of pigmented lipid droplets that may protect against UV radiation. Hyaline or white basidiospores have also been reported (Diner and Mott, 1982a; Gold and Mendgen, 1984c).

\subsubsection{Microscopic}

Mature basidiospores vary considerably in morphology, even within a single species. However, reniform (e.g., Fig. 4), round (e.g., Fig. 10), or ovate-elliptical (e.g., Fig. 2) are
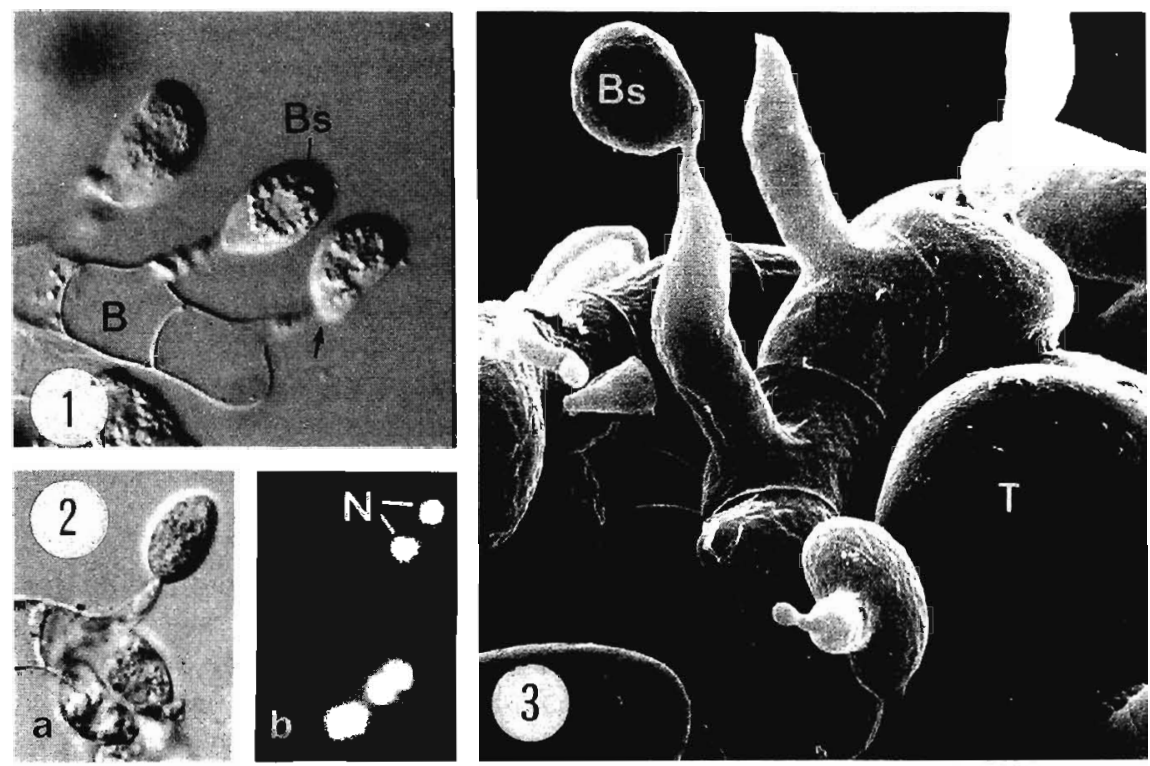

Figure 1. Metabasidium (B) of Uromyces appendiculatus. Basidiospores (Bs) are borne at the tip of the sterigmata (arrow). (750 $\times$.)

Figure 2. Light (a) and fluorescence (b) micrographs of fixed, DAPI-stained basidiospores of Uromyces appendiculatus containing one or two nuclei (N) $(620 \times)$. (From Gold and Mendgen, 1984c.)

Figure 3. Germinated teliospore $(\mathrm{T})$ of Gymnosporangium fuscum with a septate metabasidium $(\mathrm{B})$ and basidiospores (Bs). The labeled basidiospore is still attached to the sterigma. (1400×.) (Courtesy of B. Metzler. unpublished.) 


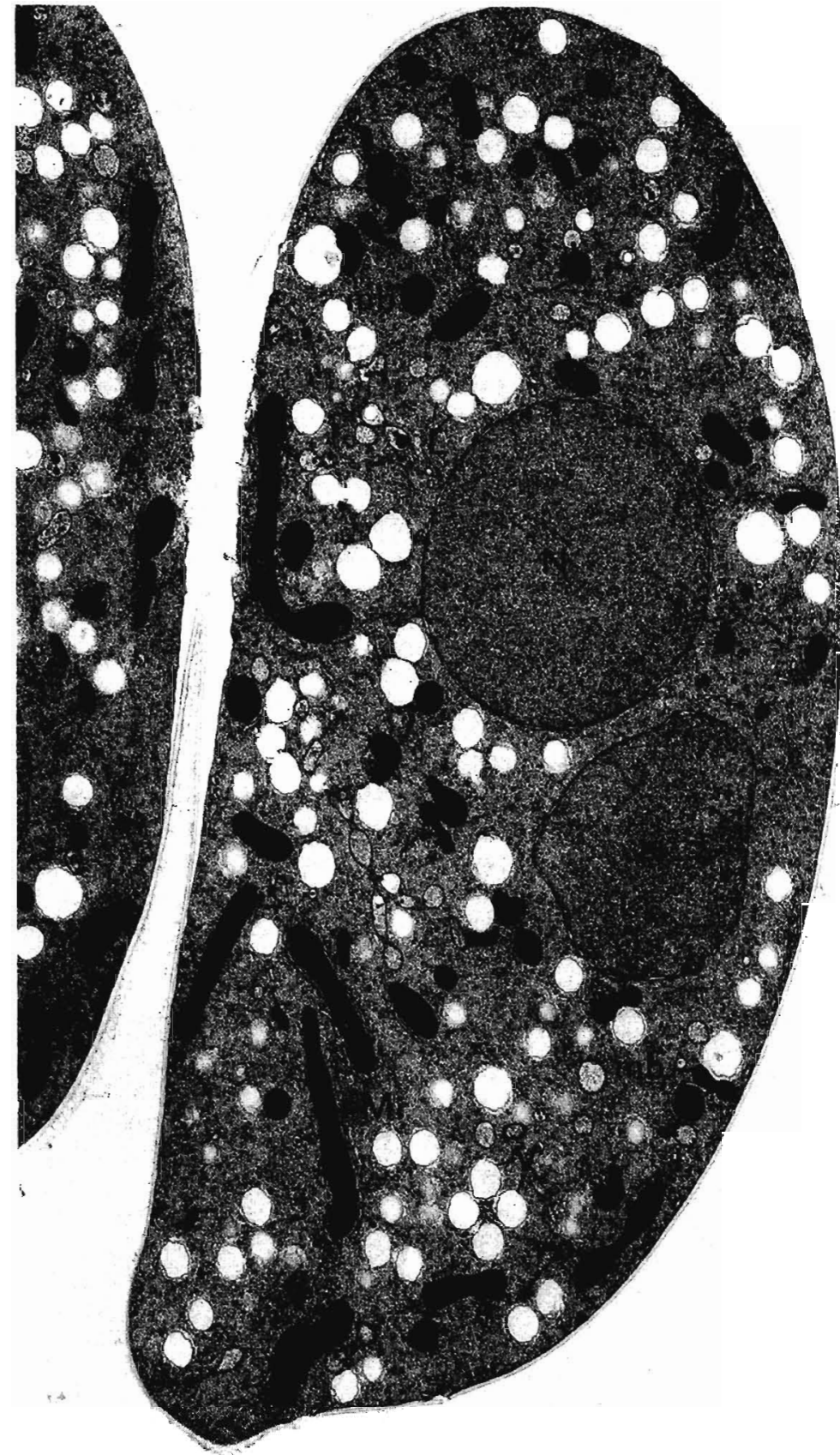

Figure 4. Longitudinal section through a basidiospore of Gymnosporangium juniperi-virginianae prepared for TEM by freeze substitution. Nuclei $(\mathrm{N})$, lipid bodies $(\mathrm{L})$, mitochondria $(\mathrm{Mi})$, microbodies $(\mathrm{mb})$, and vacuoles $(\mathrm{V})$ are shown. $(12,070 \times$.) (From Mims et al., 1988.) 
common shapes. Sizes range from $3 \times 4 \mu \mathrm{m}$ (e.g., Cronartium flaccidum) to $14 \times 25 \mu \mathrm{m}$ (e.g., Coleosporium tussilaginis). All basidiospores that have been examined by conventional SEM are smooth or slightly wrinkled (e.g., Fig. 25) and bear a prominent apiculus (Fig. 26).

When examined by TEM, the spore wall appears thin $(0.05-0.25 \mu \mathrm{m})$ in transverse section and consists of a single or a double layer. In the hilar region a thin, electron-dense outer layer is more pronounced in several species (Metzler, 1982; Bauer and Oberwinkler, 1988; Mims, 1977; Mims et al., 1988). Preformed germ pores are not present. Basidiospores have a densely packed protoplasm and typically contain two nuclei, microtubules, and endoplasmic reticulum (ER) (Fig. 4). Filasomes and tubular-vesicular complexes (TVC) were detected in germinating basidiospores preserved by ultrarapid freezing and freeze substitution protocols (Mims and Richardson, 1989). TVC seem to include the Golgi apparatus of the cell (Welter et al., 1988) and were tentatively distinguished as TVC 1 and TVC 2 (Figs. 5, 6). TVC 1 may be derived from the ER and has only been found in fungal structures growing within the leaf. TVC 1 seems to be involved in secretion (Knauf and Mendgen, 1988). TVC 2 resembles single cisternae of the dictyosomes. An obvious spatial relationship between vacuoles, lipid bodies, and microbodies interconnected by strands of ER has been observed (Fig. 4) (Gold and Mendgen, 1984a; Mims et al., 1988). Such pronounced organization is presumably related to the metabolic activities of germination, particularly the utilization of lipid reserves (Mendgen, 1973).

\subsection{Nuclear Condition}

Basidiospores typically contain two haploid, homokaryotic nuclei at maturity. During teliospore germination the diploid nucleus undergoes meiosis, followed by a mitosis, usually after each daughter nucleus has migrated into a basidiospore initial (Fig. 2) (Gold and Mendgen, 1984c). Binucleate basidiospores were first observed by Poirault and Raciborski (1895) and Sappin-Trouffy (1896), a condition confirmed by subsequent reports (Hoffman, 1912; Ashworth,
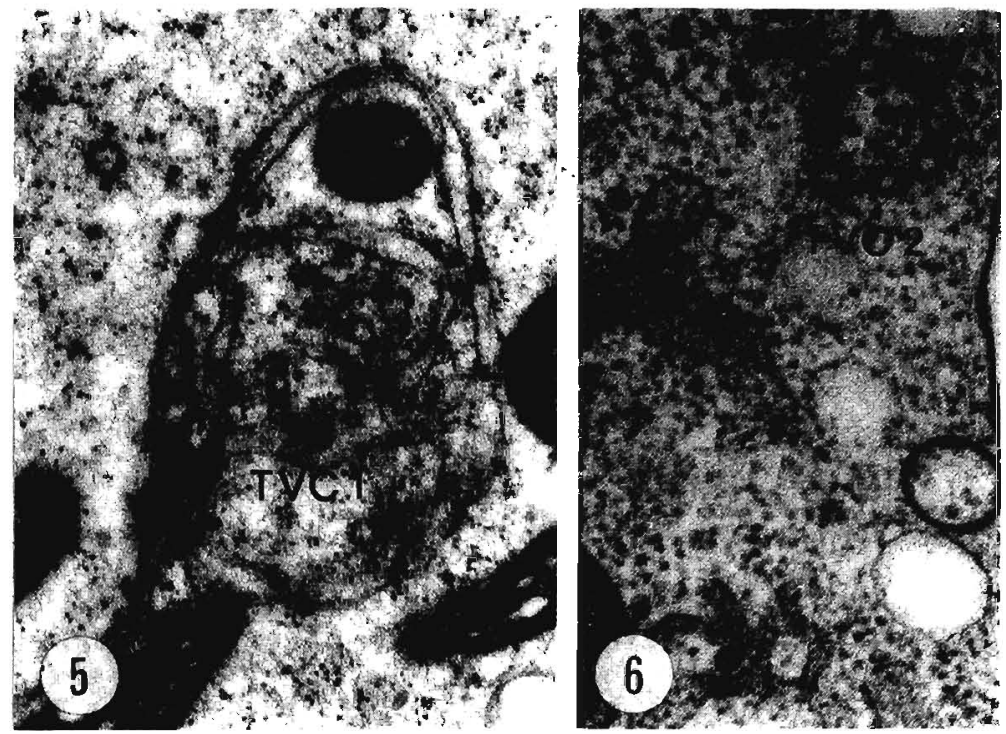

Figures 5 and 6 . Tubular-vesicular complexes (TVC) in intercellular hyphae of basidiospore-derived infections of Uromyces appendiculatus. Figure 5. TVC 1 may be part of the endoplasmic reticulum. $(35.000 \times$.) Figure 6 . TVC 2 appears similar to dictyosomes. $(60,000 \times$.) (Courtesy of L. Bruscaglioni, unpublished.) 
1935; Savile, 1939; Thirumalachar, 1939; Kapooria, 1971; Gopinathan Nair, 1972; Bauer, 1986; Mims et al., 1988; see Allen, 1933; Petersen, 1974; Anikster, 1983; Gold and Mendgen, 1984c, for additional references). Other studies have described species with simplified two- or threecelled metabasidia (Petersen, 1974) and have also revealed unique alternative development patterns, including binucleate, heterokaryotic (self-fertile) (Lindfors, 1924; Thirumalachar, 1945; Anikster and Wahl, 1985) and quadranucleate (Olive, 1949; Kapooria, 1968; Kohno et al., 1975 ) basidiospores. Anikster and co-workers (1980) and Petersen (1974) have summarized the numerous variations and consequences of functionally heterokaryotic basidiospores. Recent quantitative studies (Kapooria and Zadoks, 1973; Hansen and Patton, 1975; Anikster, 1983; Gold and Mendgen, 1984c) and numerous descriptive or semiquantitative reports confirm that binucleate spores are clearly the predominant form.

\subsection{Germination}

After being deposited on their host, basidiospores can germinate within a few hours. Germination may follow two characteristic forms (Fig. 7): either directly via germ tubes (Fig. 8) or indirectly via formation of secondary spores (Fig. 9). The pattern followed is dependent on environmental conditions and the host surface (Ragazzi and Dellavalle Fedi, 1982; DesprezLoustau, 1986).

\subsubsection{Influence of Water}

Of the basic environmental factors influencing spore germination, water, in the form of humidity and surface moisture, appears to be the most crucial. High humidity is generally needed (Cotter, 1932; Hansen and Patton, 1975); however, the conditions required are difficult to generalize. For example, basidiospores of Cronartium ribicola (Hansen and Patton, 1975), Puccinia horiana (Kapooria and Zadoks, 1973), and Puccinia malvacearum (Ashworth, 1931) all germinate well on both water agar and dry glass slides enclosed in a moist chamber. In contrast, basidiospores of Melampsora pinitorqua on $1.5 \%$ water agar germinate equally well at humidities

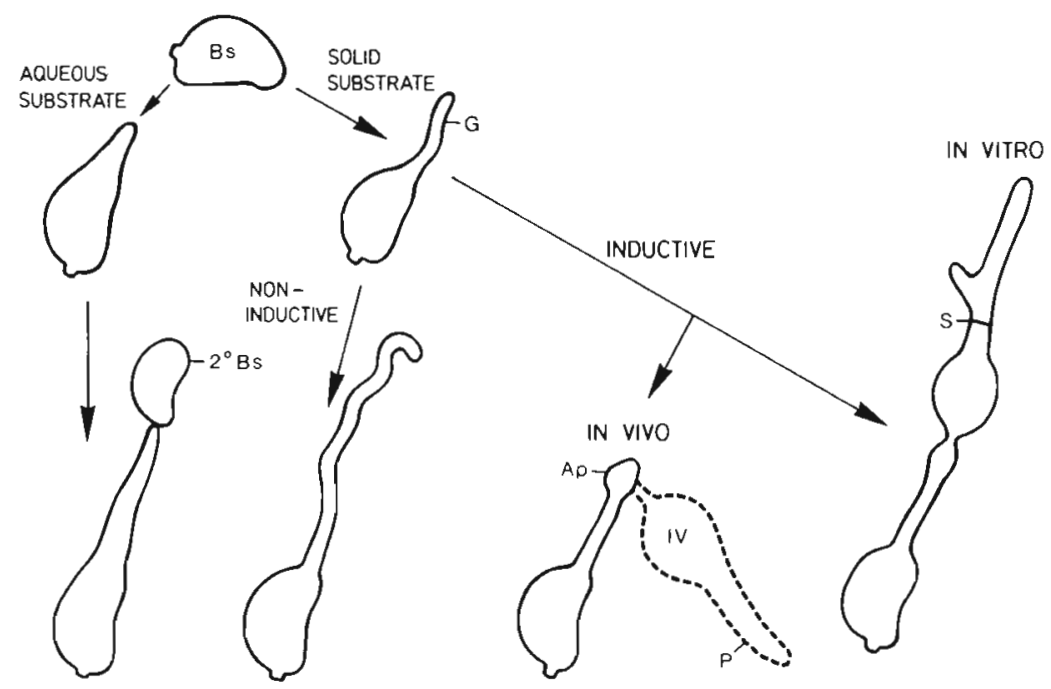

Figure 7. Diagrammatic illustration of basidiospore germination and development on various substrata. Ap, appressorium; Bs, basidiospore; $G$, germ tube; $\mathrm{lV}$, intraepidermal vesicle; $\mathrm{P}$, primary hypha; $\mathrm{S}$, septum. (Modified after Bauer, 1986.) 

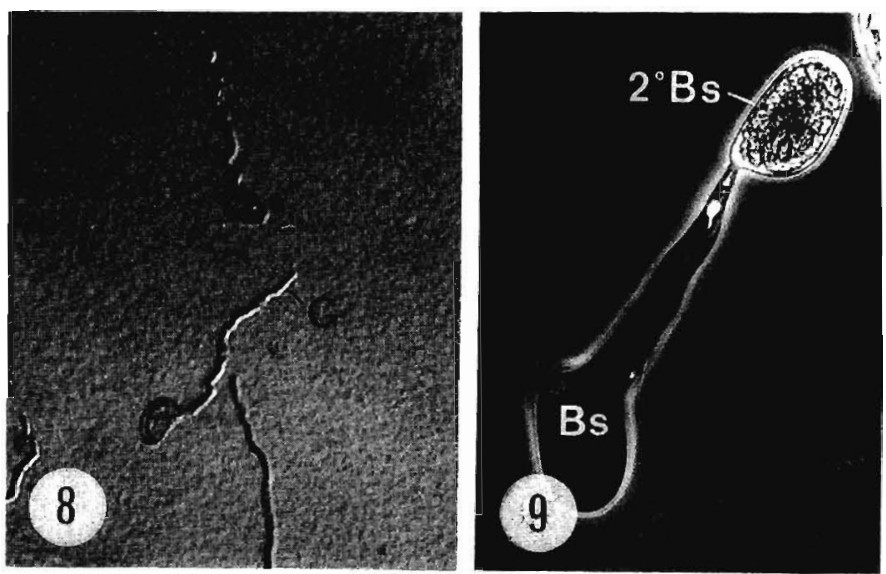

Figure 8. Basidiospore germlings of Uromyces appendiculatus on $2 \%$ water agar. Note long, thin, and wavy germ tubes (G). (290×.) (From Freytag et al., 1988.)

Figure 9. Secondary basidiospore $\left(2^{\circ} \mathrm{Bs}\right)$ of Coleosporium iussilaginis arises from the basidiospore (Bs) in a water droplet on $0.2 \%$ water agar. $(540 \times$.) (From Bauer, 1986.)

ranging from 35 to $100 \%$, but fail to germinate under any humidity conditions when incubated on glass slides (Desprez-Loustau, 1986). Differing sensitivities to surface properties of glass and/or differences in spore water content may explain these results.

Basidiospores are extremely sensitive to desiccation. When exposed to unfavorable conditions, such as low humidity or direct sunlight, they quickly lose viability (Spaulding and Rathbun-Gravatt, 1926; MacLachlan, 1935; Blank and Leathers, 1963; Gould and Shaw, 1969: Snow, 1968a). Excessive free water is also generally inhibitory to germination (Desprez-Loustau, 1986) or leads to the formation of secondary basidiospores (Figs. 7, 9) (Hansen and Patton, 1975; Bauer, 1986; Mims and Richardson, 1989). A basidiospore can produce up to six successive secondary spores (Petersen, 1974; Bauer, 1986), all equally pathogenic (Roncadori, 1968).

It has long been proposed that secondary basidiospore formation is a survival mechanism for spores exposed to improper environmental conditions (Reess, 1870; Weimer, 1917; Hansen and Patton, 1975) or nonhost substrata (Bega, 1960; Van Sickle, 1975). Bauer $(1986,1987)$ reported that unfavorable positioning on the host, such as adhesion to leaf hairs, can also signal the formation of secondary spores, and demonstrated that one of the nuclei degenerates during this process (Fig. 10).

\subsubsection{Influence of Temperature}

Many in vitro studies have demonstrated that basidiospores can germinate over a wide temperature range. For example, Hansen and Patton (1975) germinated basidiospores of Cronartium ribicola between 5 and $24^{\circ} \mathrm{C}$, with a maximum observed between 12 and $15^{\circ} \mathrm{C}$. . With the same species, Bega (1960) found germination on both water agar and host needles between I and $28^{\circ} \mathrm{C}$, but with broad maxima between 5 and $24^{\circ} \mathrm{C}$ and 13 and $20^{\circ} \mathrm{C}$, respectively. A similarly broad maximum between 8 and $20^{\circ} \mathrm{C}$ has been determined in vitro for basidiospores of $M$. pinitorqua, a species that may germinate and grow between 2 and $30^{\circ} \mathrm{C}$ (Desprez-Loustau, 1986). These results and others (Reed and Crabill, 1915; MacLachlan, 1935; Siggers, 1947; Yamada, 1956; Van Sickle, 1975; Ragazzi et al., 1986) show that basidiospores have an enormous germination potential. Thermal death has been determined between 30 and $32^{\circ} \mathrm{C}$ for a few species (Reed and Crabill, 1915; MacLachlan, 1935; Desprez-Loustau, 1986). 


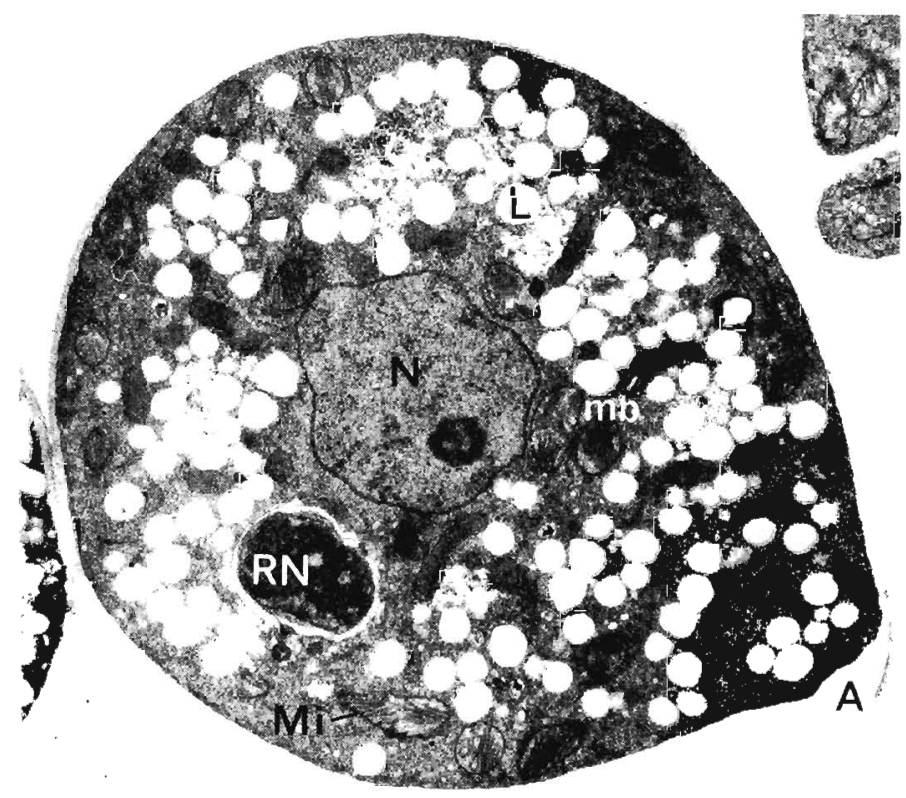

Figure 10. Basidiospore of Coleosporium asclepiadeum with intact nucleus (N) and degenerated remnant nucleus (RN) prior to secondary spore formation. A, apiculus; L, lipid body; Mi, mitochondrion; mb, microbody. $(11,500 \times$.) (From Bauer and Oberwinkler, 1988.)

\subsubsection{Influence of Light}

In order to avoid the effects of UV radiation and desiccation by direct sunlight, most basidiospores are formed and released rhythmically at night or early morning (see Gold and Mendgen, 1983). Darkness, however, is not necessary for germination. When other conditions are favorable, light has either no effect (Yamada, 1956; Bega, 1960; Diner and Mott, 1982a; Desprez-Loustau, 1986) or only a marginal negative effect (Gould and Shaw, 1969).

\subsubsection{Influence of Host Substances}

Fresh leaves of sagebrush inhibit the germination of Cronartium comandrae completely (Krebill, 1972). Leaf fragments with abundant glandular hairs (Robinson, 1914) or water-soluble exudates from Pinus pinaster inhibit germination in Puccinia malvacearum and $M$. pinitorqua (Desprez-Loustau, 1986), respectively. The inhibitory effect on $M$. pinitorqua is stronger with exudates from disease-resistant species. Water-insoluble monoterpenic compounds from epicuticular waxes are also inhibitory, although there are no differences between resistant and susceptible host species.

\subsubsection{Influence of Massing}

Massing of basidiospores has been reported to inhibit germination (Hansen and Patton, 1975). Spaulding and Rathbun-Gravatt (1926) attributed the effect to insufficient oxygen or secretion of toxic substances. Self-inhibitors of basidiospore germination per se have not been reported. 


\section{BASIDIOSPORE GERMLINGS IN VITRO}

Physiological studies of germ tube development have been limited by difficulties in obtaining sufficient spore material. Furthermore, the limited life span of basidiospores and their restricted growth pattern in axenic culture have also hindered such research.

\subsection{Germ Tube Differentiation}

\subsubsection{Influence of Environmental Conditions}

C. ribicola germ tubes grow best at $12-15^{\circ} \mathrm{C}$; however, most intraepidermal vesicles are formed between 19 and $26^{\circ} \mathrm{C}$. Incubation at $16^{\circ} \mathrm{C}$ followed by treatment at 24 or $28^{\circ} \mathrm{C}$ for $1-2 \mathrm{hr}$ increases the incidence of vesicle formation considerably (Hansen and Patton, 1975), indicating that basidiospore germ tubes can react to temperature shocks as do those of urediniospores (see Hoch and Staples, this volume).

Robinson (1914) studied the tropic effect of light on germ tube growth in Puccinia malvacearum. Freshly cast spores were illuminated unilaterally with incident light from a window. In this simple experiment the germ tubes emerged predominantly from the shadowed side of the spores, and when these were subsequently rotated through $90^{\circ}$, exhibited a marked negative phototropic response.

\subsubsection{Influence of Artificial Substrata}

The induction of infection structures in vitro depends greatly on the hardness of the substratum. For example, in water or on $0.2-0.7 \%$ water agar, spores of Gymnosporangium clavariiformae germinate with a broad germ tube and subsequently form a secondary spore (Fig. 9) (Bauer, 1987). On 1-2\% water agar, a thin, unbranched, and undifferentiated nonseptate germ tube is formed (Fig. 8). Agar concentrations around 4-5\% induce the formation of short germ tubes with appressoria (Bauer, 1986; Freytag et al., 1988). With Uromyces viciae-fabae, $U$. vignae, and $U$. appendiculatus, infection structure development may proceed as far as a vesicle (Fig. 11) or a primary hypha (Freytag et al., 1988).

Artificial membranes on agar, such as nitrocellulose (Figs. 12, 19), collodion (Fig. 13), polyethylene (Fig. 15), and dialysis tubing (Figs. 16, 17), can induce infection structures from basidiospores (Hansen and Patton, 1975; Freytag et al., 1988; Mims and Richardson, 1989). The hard cuticular surface of barley coleoptiles (R. E. Gold, unpublished) and even glass (Fig. 14) (Bauer, 1986; Freytag et al., 1988) induce the formation of appressoria, suggesting that surface recognition in the haploid stage is not very specific. In all these cases the surface hardness and the amount of water available determine whether (1) a germ tube forms, (2) a secondary spore is produced, or (3) germ tube growth continues to produce normal infection structures (see Fig. 7).

Isolated cuticles of Vicia faba, Vigna sinensis, and Phaseolus vulgaris induce the formation of infection structures of $U$. viciae-fabae, $U$. vignae, and $U$. appendiculatus, respectively (Freytag et al., 1988). Cross-inoculations show this response to be nonhost specific (S. Freytag and L. Bruscaglioni, unpublished). On leaf cuticles mounted on $2 \%$ agar, basidiospores germinate, form short germ tubes, differentiate appressoria and intraepidermal vesicles either on the surface of the cuticle (Fig. 18) or below the cuticle in the agar (S. Freytag, unpublished). Under natural conditions, such vesicles develop within host epidermal cells (Figs. 22, 23a).

\subsection{Surface Carbohydrates}

In vitro, basidiospore germ tubes may be copiously covered with an extracellular matrix (Figs. 16, 17) (Mims and Richardson, 1989). Basidiospores and germ tubes of $U$. viciae-fabae 

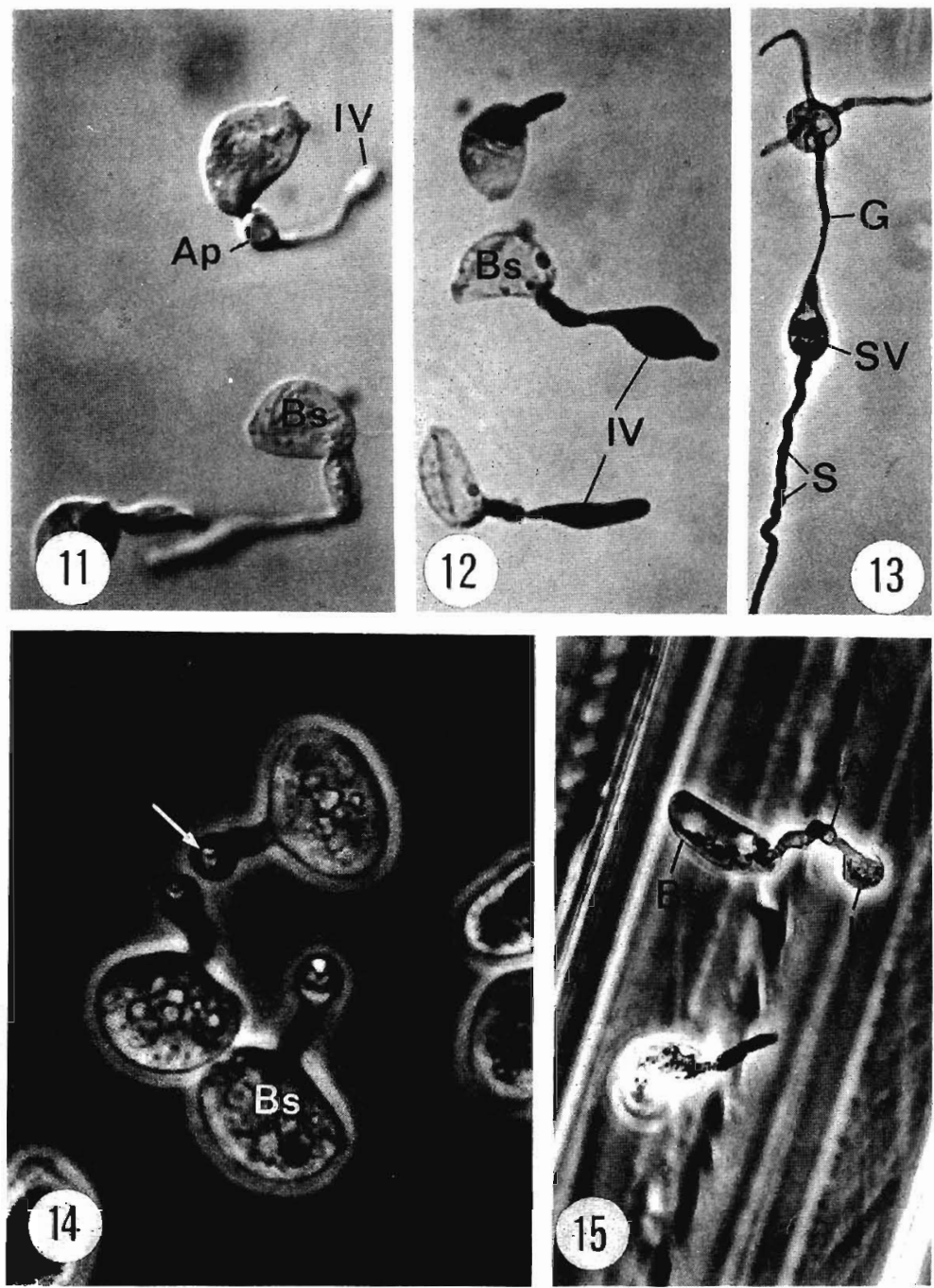

Figure 11. Basidiospore germlings of Uromyces vignae on 5\% water agar. Appressoria (Ap) of the basidiospores (Bs) are visible on the agar surface. Vesicles (IV, not in focus) form within the agar. $(640 \times$.) (From Freytag et al., 1988.)

Figure 12. Germinated basidiospore (Bs) of Uromyces vignae on nitrocellulose membrane filter showing vesicle (IV). (640×.) (From Freytag el al., 1988.)

Figure 13. Basidiospore germling of Cronartium ribicola on collodion membrane with four germ tubes (G) and pyriform vesicle (SV). Septa (S) are visible proximal to the vesicle. (420×, estimated.) (From Hansen and Patton, 1975.)

Figure 14. Basidiospore germlings of Gymnosporangium clavariiformae on glass. The appressorial ring (arrow) is clearly visible. Bs, basidiospore. (1060×.) (Courtesy of R. Bauer, unpublished.)

Figure 15. Basidiospore germlings of Uromyces appendiculatus on polyethylene sheet. One basidiospore (Bs) is shown with appressorium (Ap) and vesicle (IV). (730×.) 

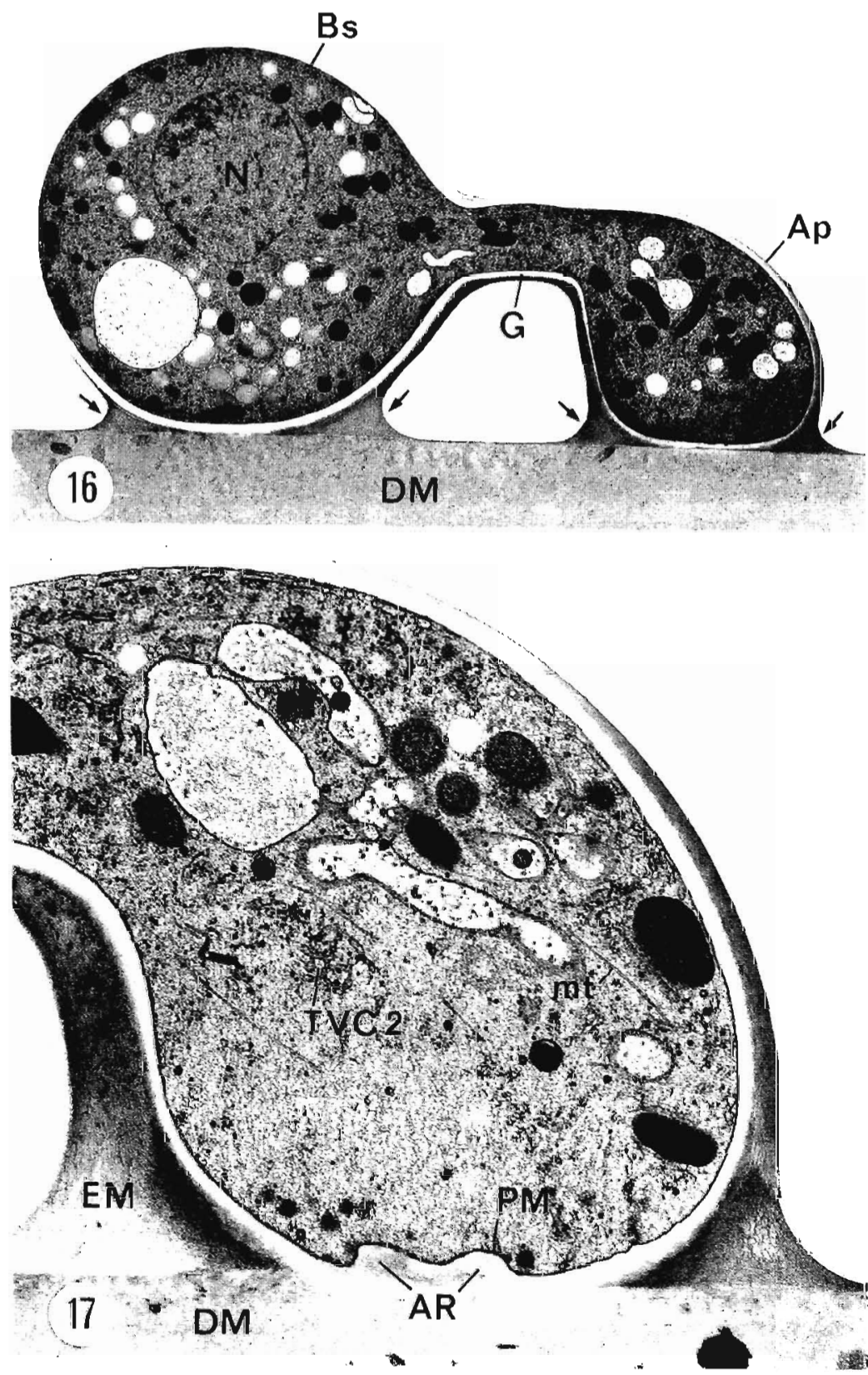

Figures 16 and 17. Basidiospore germlings of Gymnosporangium juniperi-virginianae differentiate infection structures in vitro on dialysis tubing membrane (DM). Figure 16. Longitudinal section of a germinated basidiospore (Bs) showing one of its nuclei $(\mathrm{N})$, germ tube $(\mathrm{G})$, and prominent appressorium (Ap). The electron-dense extracellular matrix (arrows) is abundant and attaches the germling to membrane. $(6500 \times$.) (From Mims and Richardson, 1989.) Figure 17. Appressorium with appressorial ring (AR) outside plasma membrane (PM) and in close contact with membrane. The extracellular matrix (EM) covers appressorium. Note microtubules (mt) and tubular-vesicular complex (TVC2). (20,000×.) (Courtesy of C. W. Mims and E. A. Richardson, unpublished.) 


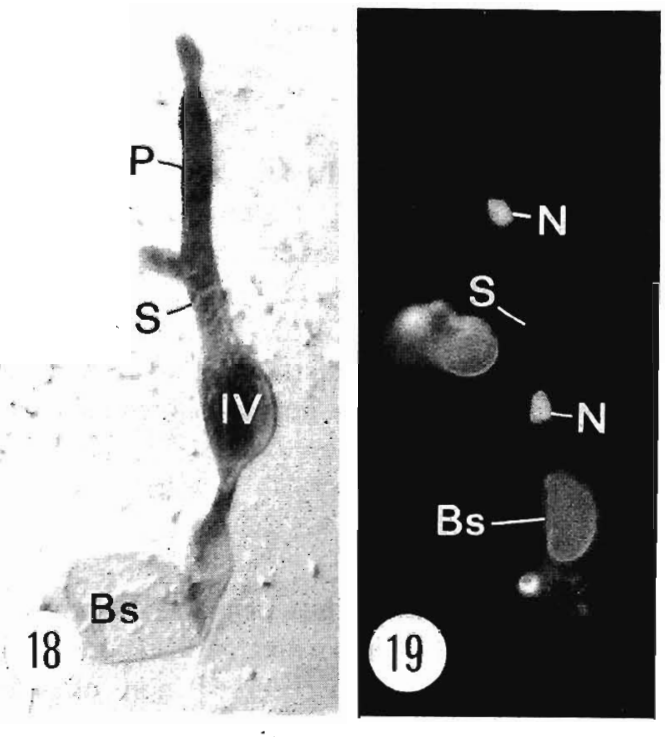

Figure 18. Germinated basidiospore (Bs) of Uromyces appendicularus on isolated host bean leaf cuticle. The vesicle (IV) and septate hypha (P) formed on the surface of the cuticle. S, septum. $(960 \times$.) (From Freytag et al., 1988.)

Figure 19. Basidiospore germling of Uromyces viciae-fabae on nitrocellulose filter after staining with DAPU calcofiuor. The hypha contains two nuclei $(\mathrm{N})$ separated by a septum $(\mathrm{S})$. Bs, basidiospore. $(500 \times$.) (Courtesy of $\mathrm{S}$. Freytag, unpublished.)

strongly bind lectins of Triticum vulgaris and Canavalia ensiformis, and weakly those of Lens culinaris, Tetragonolobus purpureas, and Ricinus communis (Fig. 20). These results suggest that they are covered with carbohydrates or glycoproteins that consist mainly of chitin, $\alpha$-D-mannose, $\alpha$-D-glucose, and some $\alpha$-L-fucose and $\beta$-D-galactose. In comparison to urediniospore-derived infection structures, which appear to cover its chitin with other carbohydrates as soon as it penetrates the plant (Mendgen et al., 1985), the basidiospore-derived infection structure reduces chitin while the affinity to other lectins remains at the same level (Fig. 20).

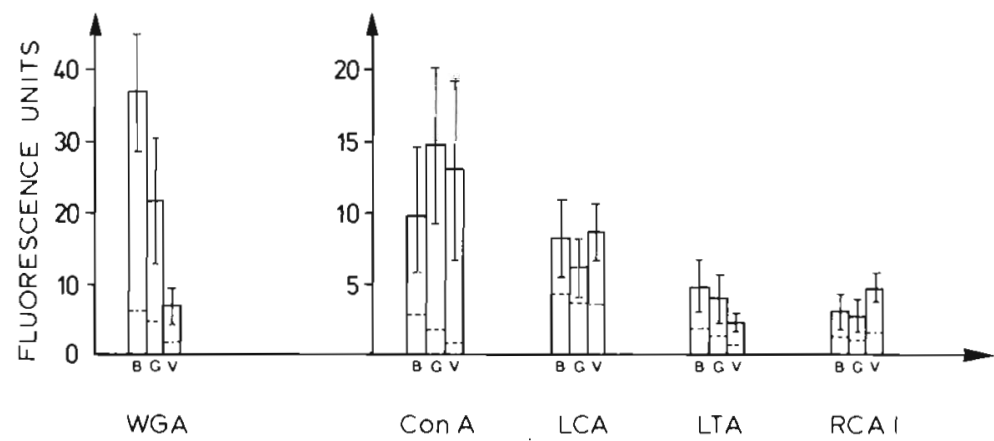

Figure 20. Affinity of some lectins to infection structures of Uromyces viciae-fabae in vitro. The lectins were labeled with FITC and the fluorescence was measured with a microscope photometer. B, basidiospore; G, germ tube; V, intraepidermal vesicle. WGA, wheat germ agglutinin; Con A, Canavalia ensiformis agglutinin; LCA, Lens culinaris agglutinin; LTA, Tetragonolobus purpureas agglutinin; RCA, Ricinus communis agglutinin. (Courtesy of S. Freytag, unpublished.) 


\section{BASIDIOSPORE GERMLINGS IN VIVO}

\subsection{Historical Perspective}

Much of the early rust work focused on basidiospore-derived infections of stem rust of cereals and coniferous tree rust diseases. de Bary (1865) demonstrated the relationship between infections of Puccinia graminis on wheat and barberry, which stimulated numerous subsequent studies on host penetration and infection (de Bary, 1866; Reess, 1870; Ráthay, 1881; Fischer, 1898 , 1901; Eriksson, 1911; Waterhouse, 1921; Allen, 1930, 1932, 1934, 1935; Nusbaum, 1935). These initial studies, often containing accurate light microscopic observations (see Figs. 21, 22), gave way to studies on the epidemiologically more important urediniospore, which dominate the literature today.

\subsection{Penetration}

The anatomy of basidiospore germination, host penetration, and the development of characteristic inter- and intracellular structures is shown diagrammatically in Figs. 23 and 28. Penetration directly through the epidermis has been observed more often than indirect, stomatal penetration. Indirect penetration is common for species that attack gymnosperms, although exceptions do occur (Figs. 24, 42). Gymnosperms have a thick-walled epidermis covered by a thick cuticle. The extreme rigidity of even young needles presents a tough physical barrier and rusts may have adapted to stomatal penetration as a response to the impenetrable host epidermis (Fischer, 1898; Patton and Johnson, 1970; Grill et al., 1980; Bauer, 1986).

\subsubsection{Development on Host Epidermis}

Basidiospores of many rusts produce a single, unbranched germ tube (Fig. 33) (Van Sickle, 1975; Kohno et al., 1977b; Jacobi et al., 1982; Metzler, 1982; Gold and Mendgen, 1984a) that generally emerges opposite the apiculus (Fig. 24) or laterally (Fig. 26). In Cronartium ribicola and $C$. asclepiadeum, several germ tubes may develop (Figs. 34, 35), which can become highly branched (Bega, 1960; Hansen and Patton, 1975; Bauer, 1986; Ragazzi et al., 1987). Gold and

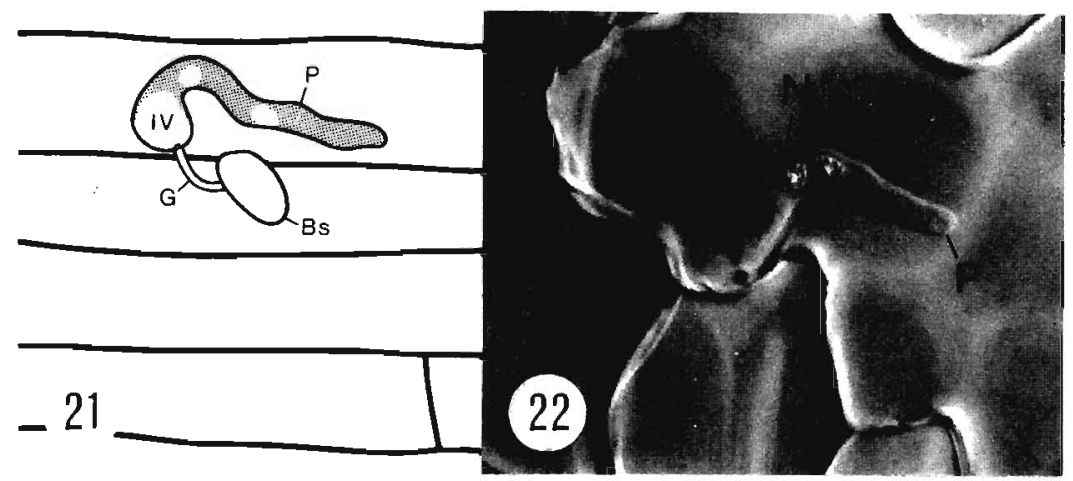

Figures 21 and 22. Epidermal infection structures. Figure 21. Diagrammatic representation. Bs, basidiospore; G, germ tube; IV, intraepidermal vesicle; P, primary hypha. (Modified after de Bary, 1863.) Figure 22. Ovate intraepidermal vesicle (IV) and primary hypha (P) of Uromyces appendiculatus are visible in leaf epidermis. Note the two nuclei $(\mathrm{N}) .(830 \times$.) (From Gold and Mendgen, 1984a.) 

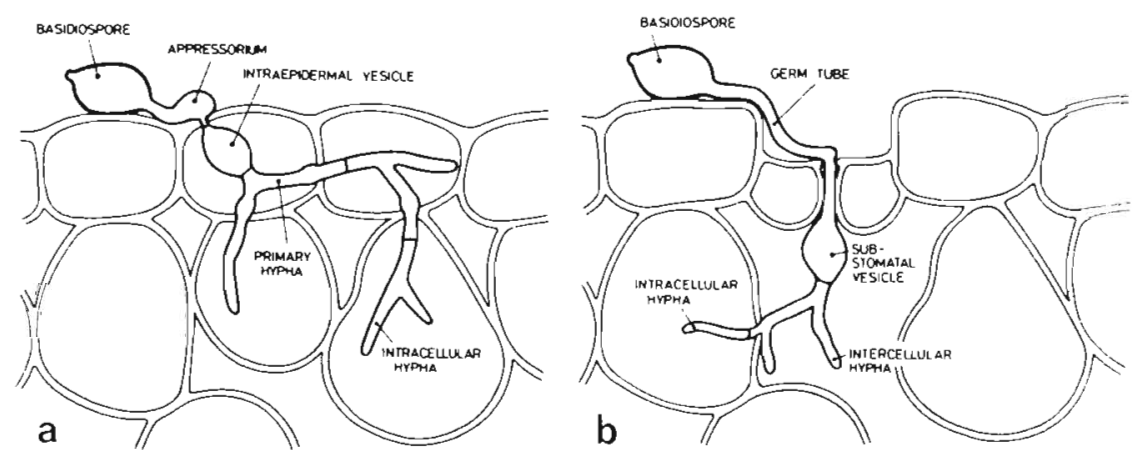

Figure 23. Diagrammatic representation of a direct-penetrating (a) and an indirect-penetrating (b) basidıospore germling.

Littlefield (1979) described branched germ tubes in Melampsora lini associated with septum formation.

In contrast to urediniospore germ tubes, which tend to grow at right angles to the epidermal ridges (Hoch and Staples, this volume), basidiospore germ tubes grow more randomly on the epidermal surface (Hansen and Patton, 1977; Gray et al., 1983). The amount of germ tube growth prior to appressorium formation varies considerably and is dependent on the selection of an appropriate penetration site (Gold and Mendgen, 1984a).

The extracellular matrix, a common feature of direct-penetrating rusts, accumulates along
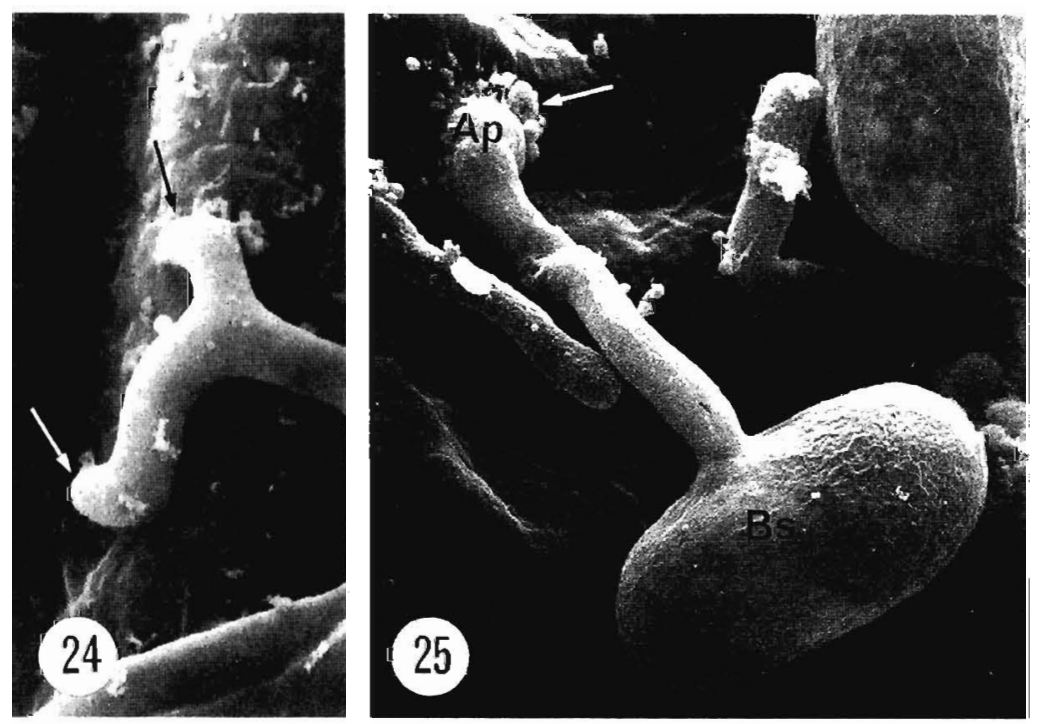

Figure 24. Sugar pine hypocotyl inoculated with vegetative hyphae of an axenic basidiospore subculture of Cronartium ribicola. Note apparent direct penetration of epidermal cell by the appressorium-like hyphal tips (arrow) closely appressed to the epidermis. (3450X.) (From Diner and Mott, 1982c.)

Figure 25. Germinated basidiospore (Bs) of Gymnosporangium fuscum on pear leaf. Note extracellular matrix material (arrow) near appressorium (Ap) at the penetration site. $(2620 \times$.) (From Metzler, 1982.) 


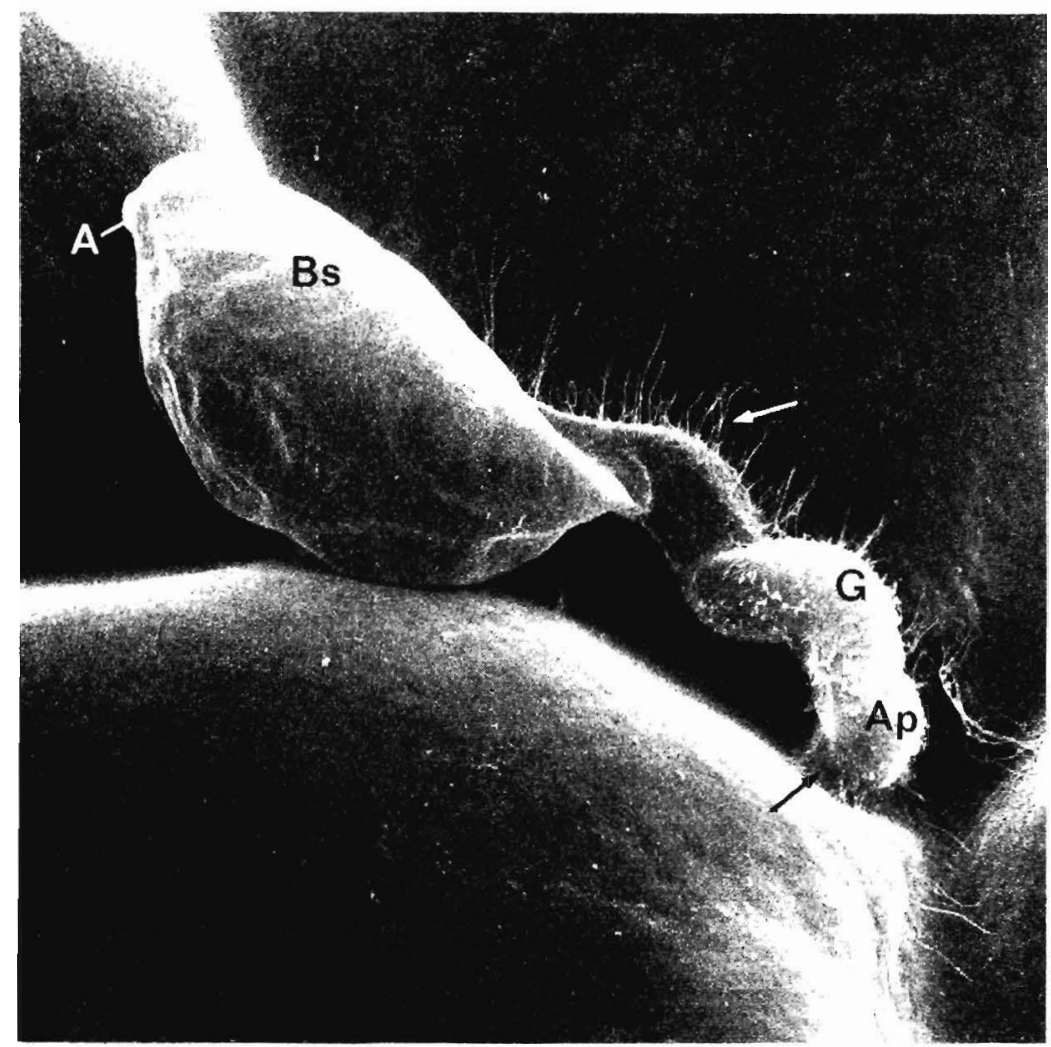

Figure 26. Direct penetration by basidiospore germling of Uromyces appendiculalus near the junction of three epidermal cells. Note the fibrouslike extracellular matrix (arrows) along the germ tube (G) and at the base of the appressorium (Ap). A, apiculus; Bs, basidiospore. (4020×.) (From Gold and Mendgen, 1984a.)

all areas of contact between the epidermis and fungus (Figs. 25, 26), especially at the periphery of the appressorium (Fig. 27) (Waterhouse, 1921; Littlefield and Heath, 1979; Metzler, 1982; Gold and Mendgen, 1984a). Jacobi and co-workers (1982) also showed that it occurs at contact points between basidiospores, suggesting a nonspecific contact response. It appears to attach the germ tube and appressorium to the plant surface, protect it from desiccation and UV radiation, and serve as a reservoir for "penetration enzymes" (see Nicholson and Epstein, this volume). The enzymes necessary for penetration may arise from the appressorial ring (Metzler, 1982), a tubular, collarlike zone that flanks the periphery of the penetration pore (Figs. 14, 28, 32) (Gold and Mendgen, 1984a; Mims and Richardson, 1989). The appressorial ring may also be important for attachment.

The formation of a slightly swollen, terminal appressorium (Figs. 24, 25, 32) by directpenetrating species occurs preferentially at or near epidermal cell junctions (Fischer, 1898; Eriksson, 1911; Melhus et al., 1920; Allen, 1932, 1935; Gold and Mendgen, 1984a). This site preference may be related to the greater availability of nutrients and moisture due to a higher rate of exosmosis in these areas and/or the chemical composition and physical structure of the wax layer that affects both $\mathrm{pH}$ and wettability of the leaf surface (Cutler et al., 1982). This characteristic appears to be independent of nuclear condition, as evidenced by direct-penetrating urediniospore germlings (see Koch and Hoppe, 1988). Appressoria do not form in indirectpenetrating species (Figs. 33-35). 


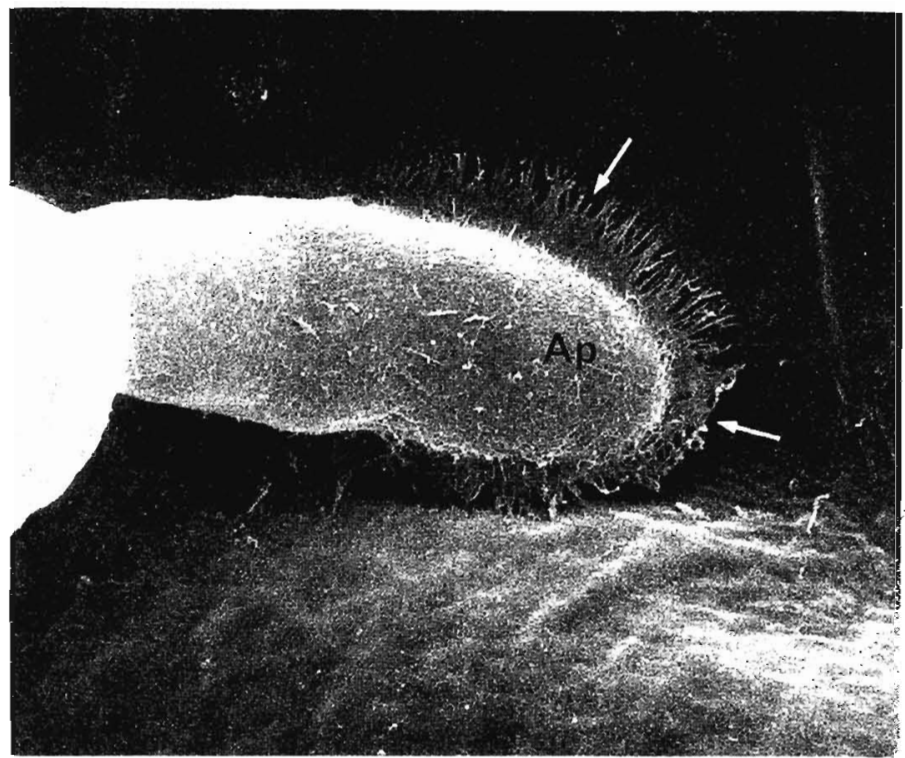

Figure 27. Apparent direct penetration near junction of two epidermal cells by basidiospore germling of Uromsces appendiculatus; note the copious deposition of the extracellular matrix (arrows). Ap. appressorium. (12.120\%.)

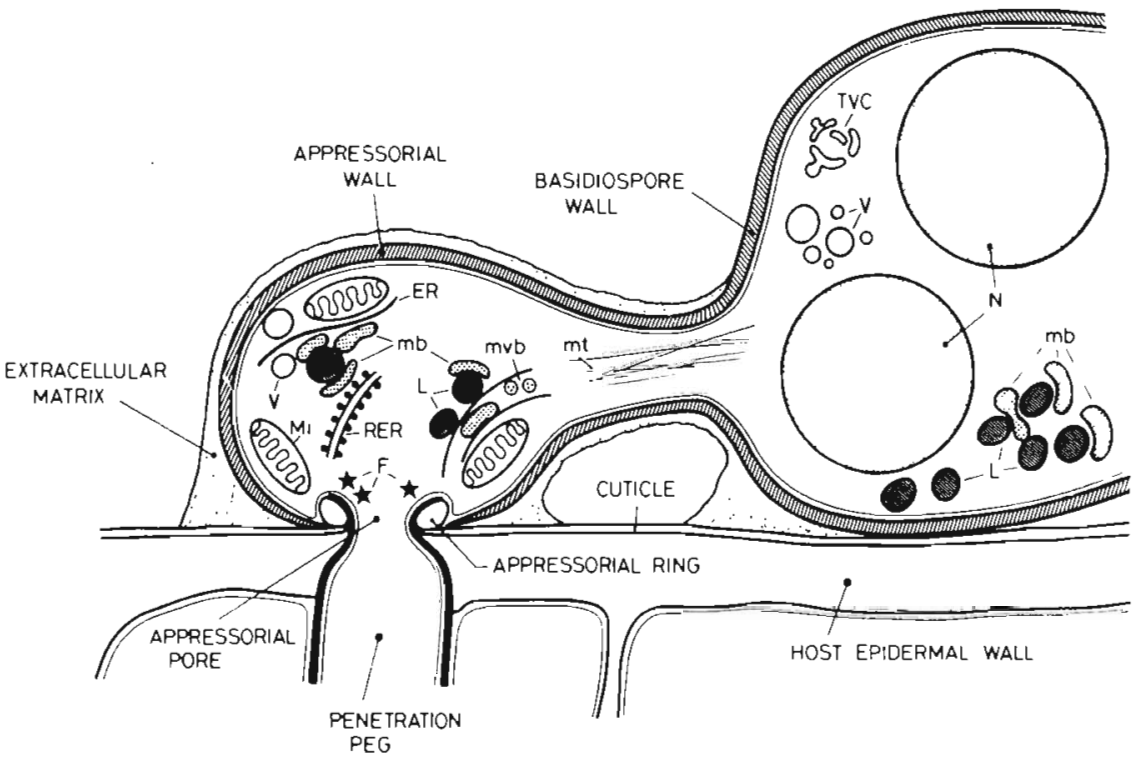

Figure 28. Detailed diagrammatic representation of basidiospore germling and epidermal penetration. (Modified after Meızler, 1982.) ER, endoplasmic reticulum; F, filasomes; L, lipid bodies; mb, microbodies; Mi, mitochondrion; $\mathrm{ml}$, microtubules; mvb, multivesicular bodies; $\mathrm{N}$, nucleus; RER, rough endoplasmic reticulum; TVC, iubular-vesicular complex; V, vacuoles. 


\subsubsection{Mode of Ingress}

The earliest stages of direct penetration are presumably effected by a narrow (diam. $=\mathrm{ca}$. $0.5 \mu \mathrm{m}$ ) peg that has only been observed by light microscopy (Fig. 29). Once through the outer region, the peg expands in diameter (Metzler, 1982; Gray et al., 1983; Gold and Mendgen, 1984a), breaches the epidermal wall, and invaginates the host plasmalemma. After a brief period of apical growth, it enlarges distally to form an ovate to oblong intraepidermal vesicle (Fig. 30). At this stage the nuclei migrate from the spore to the vesicle (see Figs. 30, 32).
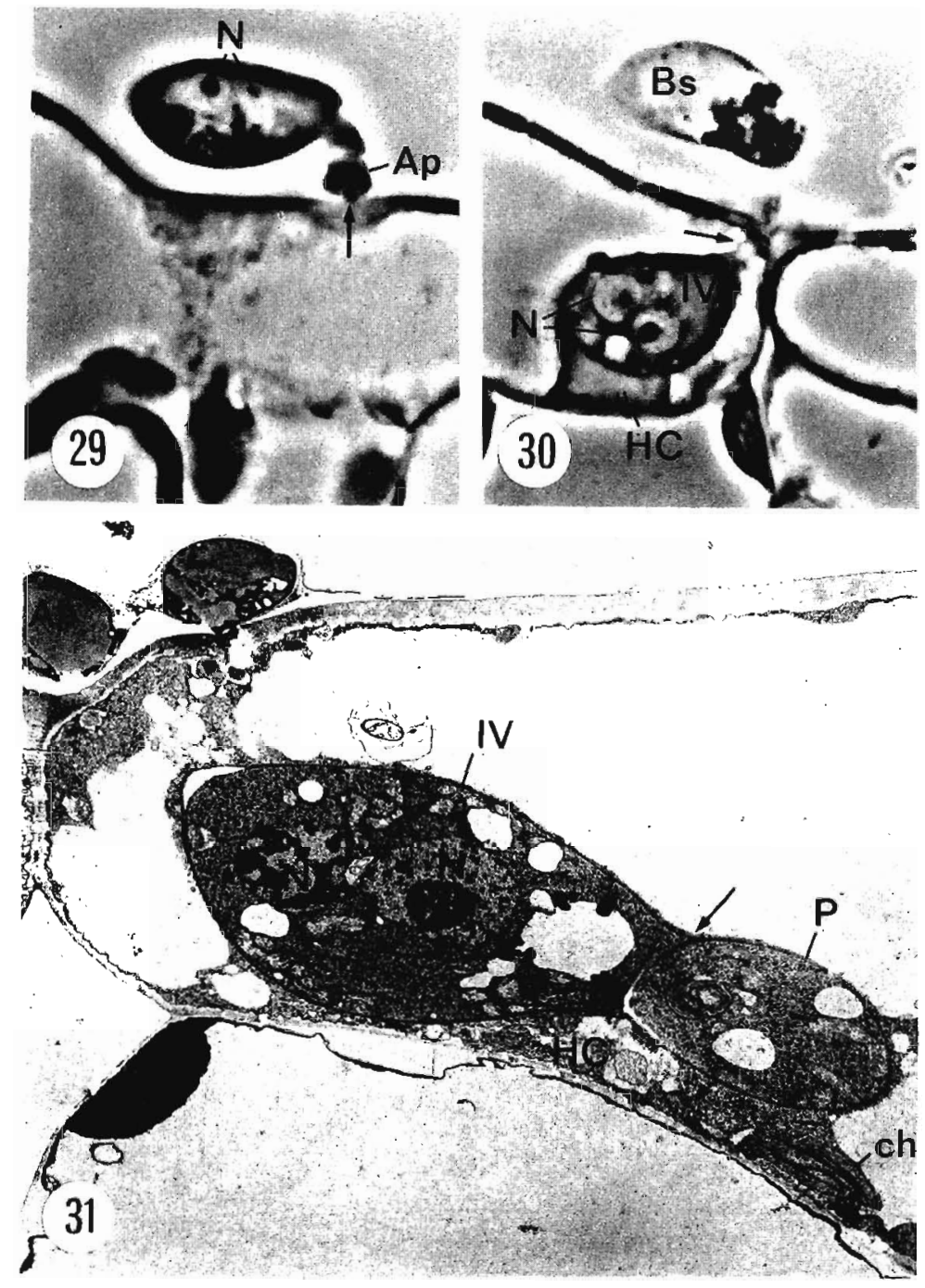

Figures 29-31. Penetration and infection of bean epidermis by Uromyces appendicularus. Figure 29. Initial stage of penetration. Binucleate basidiospore germling with appressorium (Ap) and phase-dark penetration peg (arrow). N, nucleus. (1500×.) (From Gold and Mendgen, 1984a.) Figure 30. The two nuclei (N) and cytoplasm have migrated from the basidiospore (Bs) through the narrow penetration peg (arrow) into the intraepidermal vesicle (IV). Note aggregation of host cytoplasm (HC) in the invaded epidermal cell. (1390×.) (From Gold and Mendgen, 1984a.) Figure 31. TEM of penetration site showing appressorium (Ap), intraepidermal vesicle (IV) with two nuclei $(\mathrm{N})$ and primary hypha $(\mathrm{P})$, separated by a septum (arrow). Note aggregation of host cytoplasm (HC) and chloroplast $(\mathrm{ch})$ below primary hypha. $(3540 \times$.) 


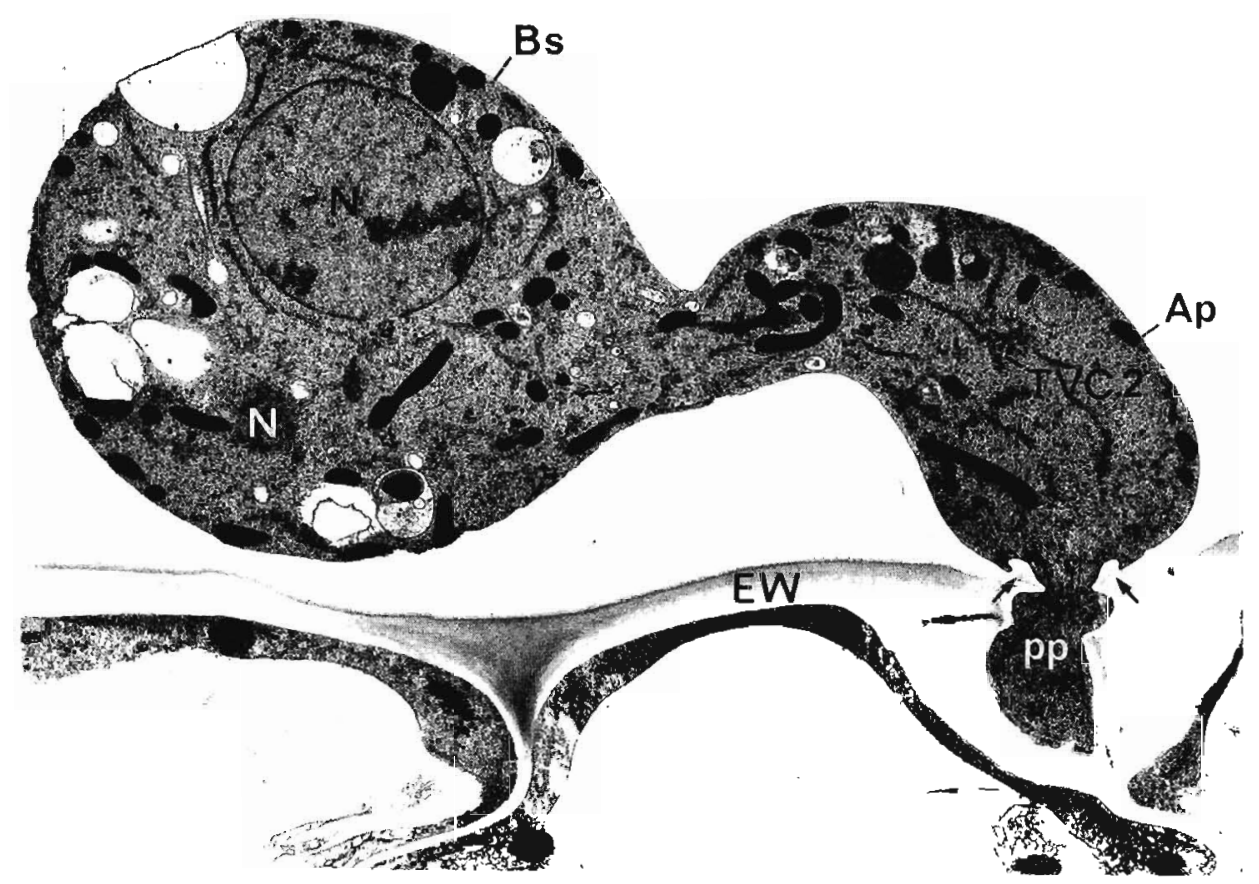

Figure 32. Gymnosporangium juniperi-virginianae on susceptible apple leaf prepared for TEM by freeze substitution. Penetration peg (pp) from appressorium (Ap) has grown through epidermal wall (EW). The appressorial ring (arrows) is visible at the point of penetration. Only one of the two nuclei $(\mathrm{N})$ is clearly visible in the basidiospore (Bs). (8000×.) (From Mims and Richardson, 1989.)

de Bary (1884) reported that the penetration pore becomes plugged after migration of the spore protoplast into the intraepidermal vesicle. Ultrastructural evidence of this was presented by Metzler (1982) as a septumlike structure in the neck region of the vesicle and by Gold and Mendgen (1984a) as an electron-dense occlusion of the penetration pore. Normal septum formation has been shown in Cronaritum fusiforme (Fig. 43) (Gray et al., 1983).

The average minimum time for penetration and formation of a vesicle is $4-6 \mathrm{hr}$ (Weimer, 1917; Waterhouse, 1921; Snow, 1968b; Van Sickle, 1975; Gold and Mendgen, 1984a), although periods of up to $24 \mathrm{hr}$ have also been reported (Allen, 1932, 1935; Nusbaum, 1935; Kohno et al. , 1977a). Light has either no influence (Hansen and Patton, 1975; Gold and Mendgen, 1984a) or a small inhibitory effect (Cotter, 1932).

\subsection{Differentiation of Infection Structures}

In direct-penetrating species, the vesicle forms within an epidermal cell and gives rise via apical growth to the primary hypha (Figs. 31, 37, 43) (Allen, 1983; Gold and Mendgen, 1984a). The primary hypha develops rapidly into a branched, multicellular network of mycelia (Fig. 41). Growth directly into neighboring epidermal cells (Figs. 37, 38, 41) and subtending palisade parenchyma is common (Figs. 39,40) as is excellular growth into intercellular spaces (Figs. 42, 43). Here, the invaginated plasmalemma of the epidermal cell becomes reunited with the native plasmalemma at points directly adjacent to the exit site (Fig. 43) (Gray et al., 1983). Once the hyphae reach the intercellular spaces, extensive ramification of the tissue occurs (Fig. 44) (Gold et al., 1979; Grill et al., 1980). 

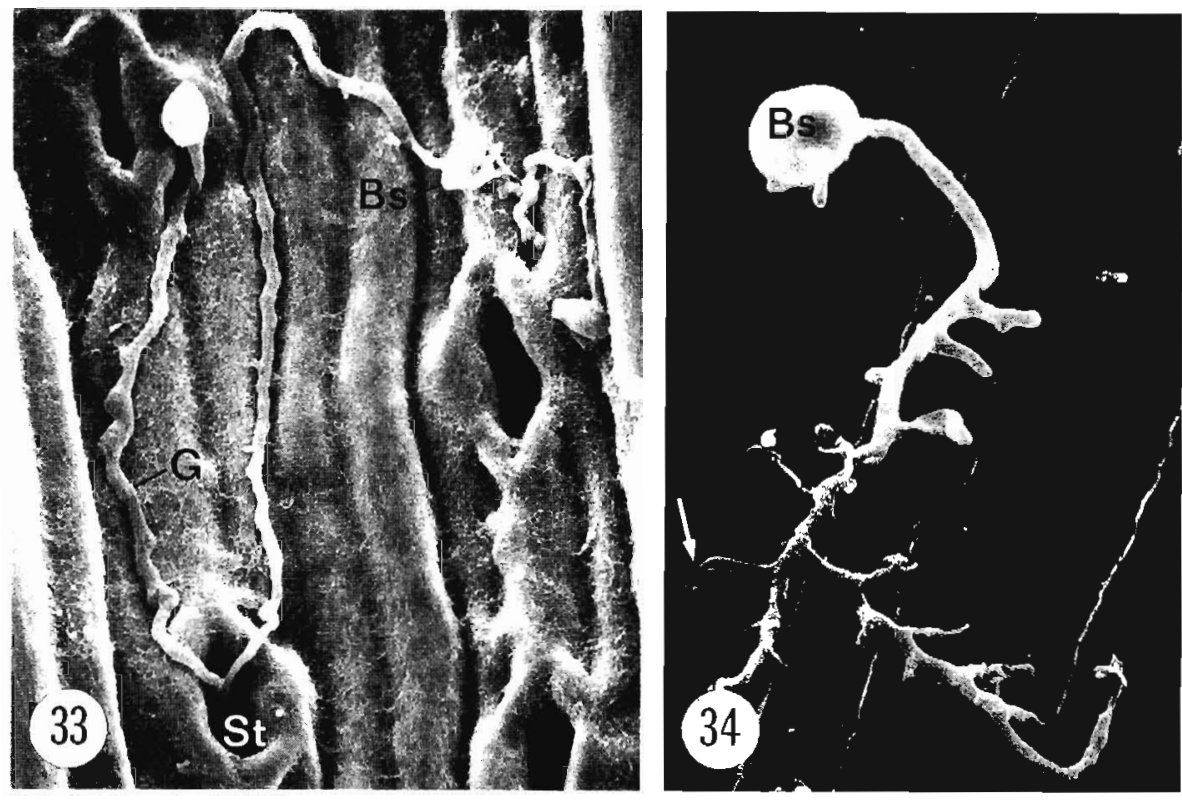

Figure 33. Indirect penetration of Pinus pinaster needle by germ tubes (G) of basidiospores of Cronartium flaccidum. Bs, basidiospore. St, stoma. (625×.) (From Ragazzi et al., 1987.)

Figure 34. Basidiospore germling of Coleosporium tussilaginis produces a highly branched germ tube on a needle of Scotch pine. Penetration of host through host stoma (arrow). Bs, basidiospore. (610×.) (From Bauer. 1986.)

In indirect-penetrating species, intercellular hyphae are derived from a vesicle that forms in the substomatal chamber (Fig. 36). Further development occurs via infection structures equivalent to those of direct-penetrating species.

The bi- or multinucleate condition remains until development of the primary hypha and subsequent infection structures. Thereafter, many rusts revert to the mononucleate condition (Eriksson, 1911; Colley, 1918; Allen, 1930, 1935; Ashworth, 1935; Nusbaum, 1935; Metzler, 1980; Freytag et al., 1988), but the binucleate (Lindfors, 1924; Thirumalachar, 1939; Kohno et al., 1977b) or multinucleate (Allen, 1934; B. Müller, unpublished) condition persists in others.

Ultrastructural studies often refer to an amorphous, electron-opaque extracellular matrix between the host and the intercellular hyphae (Fig. 45) (Harder, 1978; Borland and Mims, 1980; Al-Khesraji and Lösel, 1981; Longo et al., 1982; Gray et al., 1983; Hopkin and Reid, 1988). The origin and function of this material are uncertain, but many authors assume it to be of fungal origin and to act as an aid to attachment (Littlefield and Heath, 1979; Harder and Chong, 1984; Hopkin and Reid, 1988). It may also be involved in signal exchange between host and parasite (Mendgen el al., 1988).

Intercellular hyphae grow in contact with mesophyll cells and enter them to form intracellular hyphae (Fig. 48). The morphology of intracellular hyphae has been described in detail recently by Littlefield and Heath (1979), Harder and Chong (1984), and Hopkin and Reid (1988) and thus need not be repeated here. A characteristic of intracellular hyphae is the septum near the site of penetration either just outside (Figs. 46, 48) or inside (Figs. 49, 50) the host cell wall. Septum formation appears associated with a differentiation of intracellular infection structures. A highly conserved feature is the fingerlike or filamentous growth habit (Figs. 46-51). Conventional TEM shows no evidence of a definable neck ring (Harder and Chong, 1984). The extrahyphal 

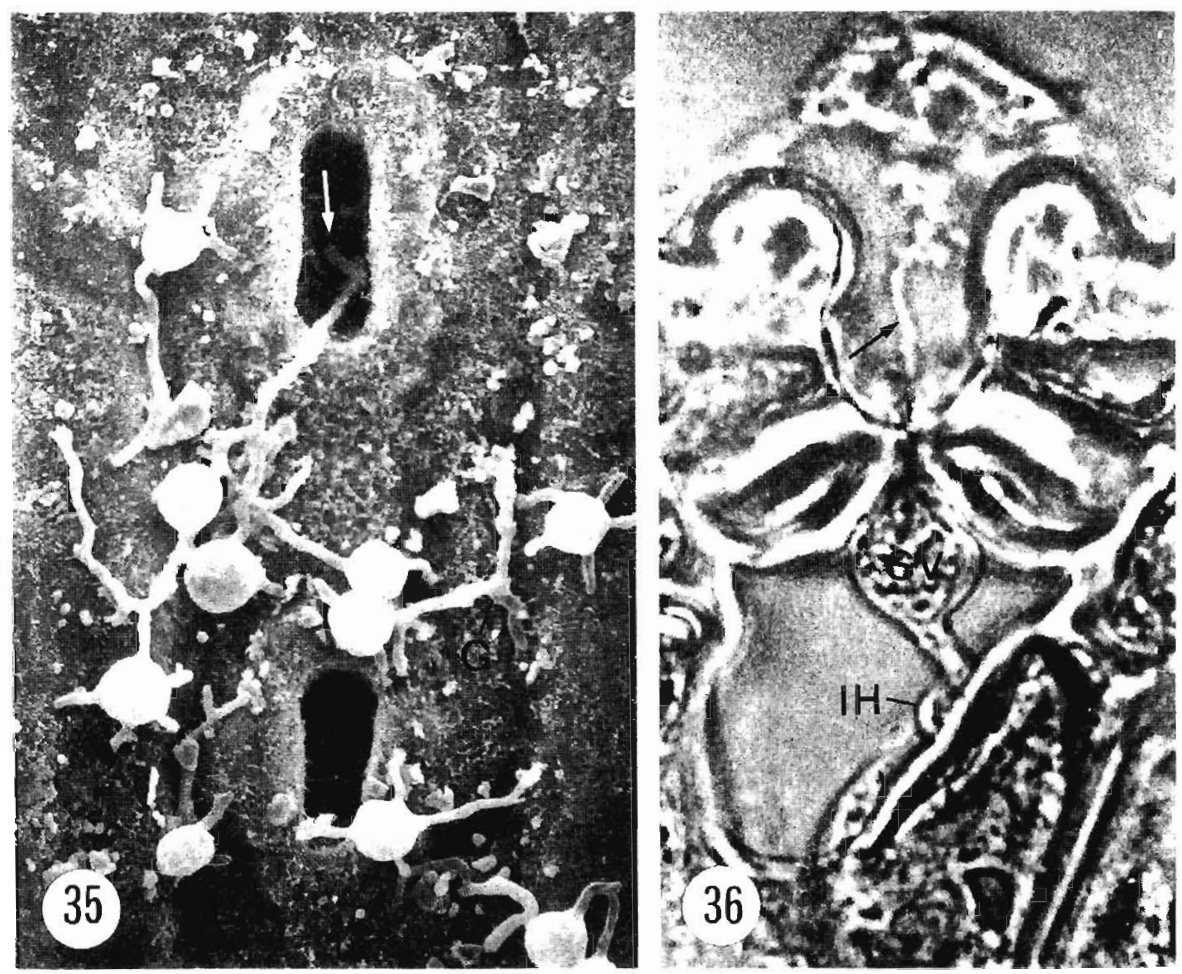

Figures 35 and 36. Development of Cronartium ribicola before and after stomatal penetration of needles of eastern white pine. Figure 35. Penetration by basidiospore germling through host stoma (arrow). Note branched germ tube $(\mathrm{G})$ and lack of prominent appressorium. (600x.) (From Patton and Spear, 1980.) Figure 36. Cross section of stomatal penetration of secondary needle. Germ tube of the basidiospore penetrated between guard cells (arrow) to form substomatal vesicle (SV) and intercellular hypha (IH). (900x, estimated.) (From Patton and Johnson, 1970.)

membrane formed by the host usually stains weakly with PACP (a stain for plasma membranes) and lacks ATPase activity (Woods and Gay, 1987). The extrahyphal matrix is more pronounced around the distal end of intracellular hyphae and stains more intensively for polysaccharides (Chong et al., 1981).

Intracellular hyphae commonly do not terminate within host cells. Several light- (Fig. 52) (Colley, 1918; Allen, 1930; Pady, 1935; Gold and Mendgen, 1984b) and electron-microscopic studies (Figs. 53, 54) (Gold et al., 1979; Littlefield and Heath, 1979; Longo and Naldini Longo, 1982; Gray et al., 1983; Gold and Mendgen, 1984b) have confirmed this. Improved methods of location (Zeyen and Bushnell, 1981) should promote future microscopical analyses of intracellular infection structures.

\subsection{Host Response}

Many investigators have taken a microscopical approach to study the incompatible interaction. The results of these studies suggest several mechanisms for resistance. On Pinus sylvestris, a relatively resistant species, basidiospore germination was reduced and delayed compared to more susceptible species (Ragazzi and Dellavalle Fedi, 1982). Natural occlusion of the stomata of Pinus 


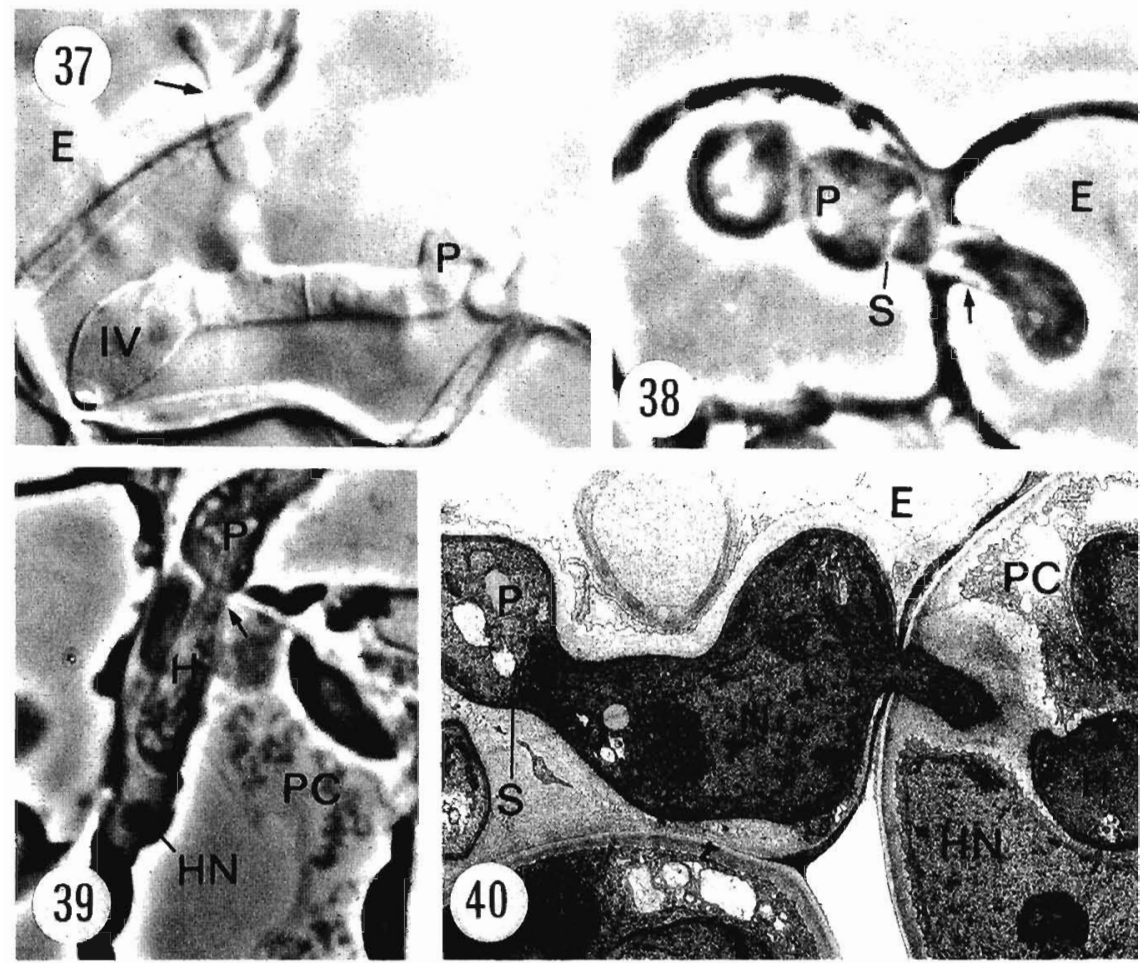

Figures 37-39. Development of Uromyces appendiculatus in bean epidermis as seen in whole leaf samples or in cross section. (From Gold and Mendgen, 1984a.) Figure 37.A branch of the primary hypha (P) penetrates into an adjacent epidermal cell $(\mathrm{E})$ at arrow. IV, intraepidermal vesicle. $(970 \times$.) Figure 38 . Primary hypha $(\mathrm{P})$ grows into adjacent epidermal cell (E). Note septum (S) proximal to penetration point and the phase-light collarlike wall apposition (arrow) of the anticlinal wall. $(1770 \times$.) Figure 39. Growth of the primary hypha (P) into a palisade parenchyma cell (PC) at arrow. The nucleus (HN) of the PC is closely associated with apex of the intracellular hypha (H). (I560X.)

Figure 40. Transcellular penetration site of Gymnosporangium fuscum. The primary hypha (P) grew from an epidermal cell (E) into a subtending palisade parenchyma cell (PC). Abundant cell wall appositional deposits are associated with the transcellular hypha. Note fungal nucleus (N),-narrow penetration site and host nucleus (HN) closely appressed to the intracellular hypha $(\mathrm{H})$. S, septum. $(5180 \times$.) (Courtesy of B. Metzler, unpublished.)

strobus seedlings with wax (Fig. 55) seems to reduce the penetration of Cronartium ribicola and the number of needle lesions (Patton and Spear, 1980). However, most other reports on this hostpathogen system suggest that resistance is based on hypersensitive reactions (Kinloch and Littlefield, 1977; Diner and Mott, 1982b). Furthermore, Grill and co-workers (1980) reported that wax occlusions do not hinder penetration by Chrysomyxa abietis. They suggested that other physiological factors are responsible for the resistance observed. The thickness of the cuticle has been proposed as a factor preventing direct penetration (Melhus et al., 1920; Melander and Craigie, 1927), although this has not been confirmed in other systems (Reed and Crabill, 1915; Ashworth, 1931; Nusbaum, 1935).

In tissue with hypersensitive lesions, necrosis of host cells (Fig. 57) and host cell wall appositions (Fig. 58) have been observed (Robb et al., 1975; Walkinshaw, 1978; Gray and Amerson, 1983). The hypersensitive response may be triggered by attempted penetration of the 

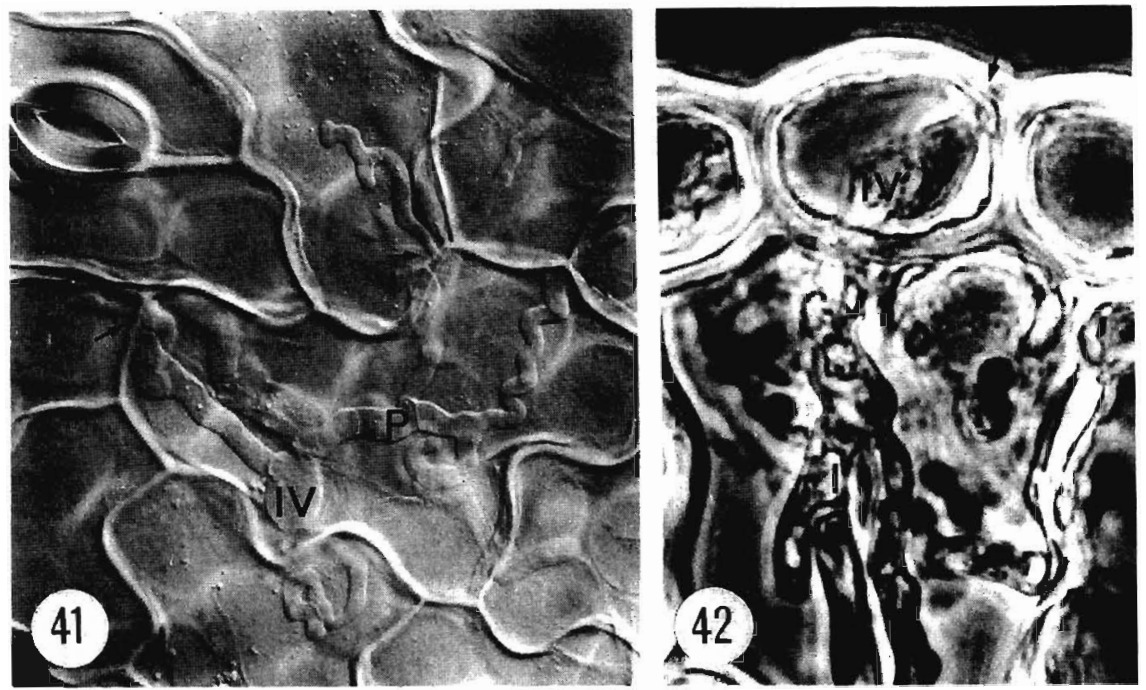

Figure 41. Highly branched, multicellular primary hypha (P) of Uromyces appendiculatus. Transcellular penetration sites are shown at arrows. IV, intraepidermal vesicle. $(540 \times$.

Figure 42. Direct penetration (arrow) by Cronartium fusiforme in needle of slash pine seedling. An ovate intraepidermal vesicle (IV) developed in the epidermal cell, prior to forming an intercellular mycelium (I). $(1150 \times$.$) (From Miller el al., 1980.)$

host epidermis (Fig. 56) or by dead or encased haustoria (Jonsson et al., 1978; Gray and Amerson, 1983).

As most studies have focused on tree rusts, the practical value of the described resistance mechanisms can only be evaluated after long-term field trials (Kuhlmann, 1988).

\section{CONCLUSIONS}

Recent studies on basidiospores and their germlings have centered around ultrastructural and morphological descriptions of the penetration and infection process, with particular emphasis on the morphology of intracellular infection structures. In contrast to urediniospore research, less emphasis has been given to biochemical and physiological aspects of germination and differentiation of infection structures. Such information is crucial to the understanding of disease initiation and in the development of improved plant disease control methods.

The fact that two haploid, homokaryotic nuclei in basidiospores versus the heterokaryotic condition in urediniospores can effect significantly different penetration and infection patterns on the same host merits further investigation. Apparently, when complementary nuclei are brought together into the same cytoplasm, different parts of the fungal genome are expressed, as evidenced by the distinct penetration and infection process initiated by urediniospores. Future studies should include parallel experiments with basidiospores and urediniospores of the same species for a better understanding of the nuclear control of differentiation processes. 


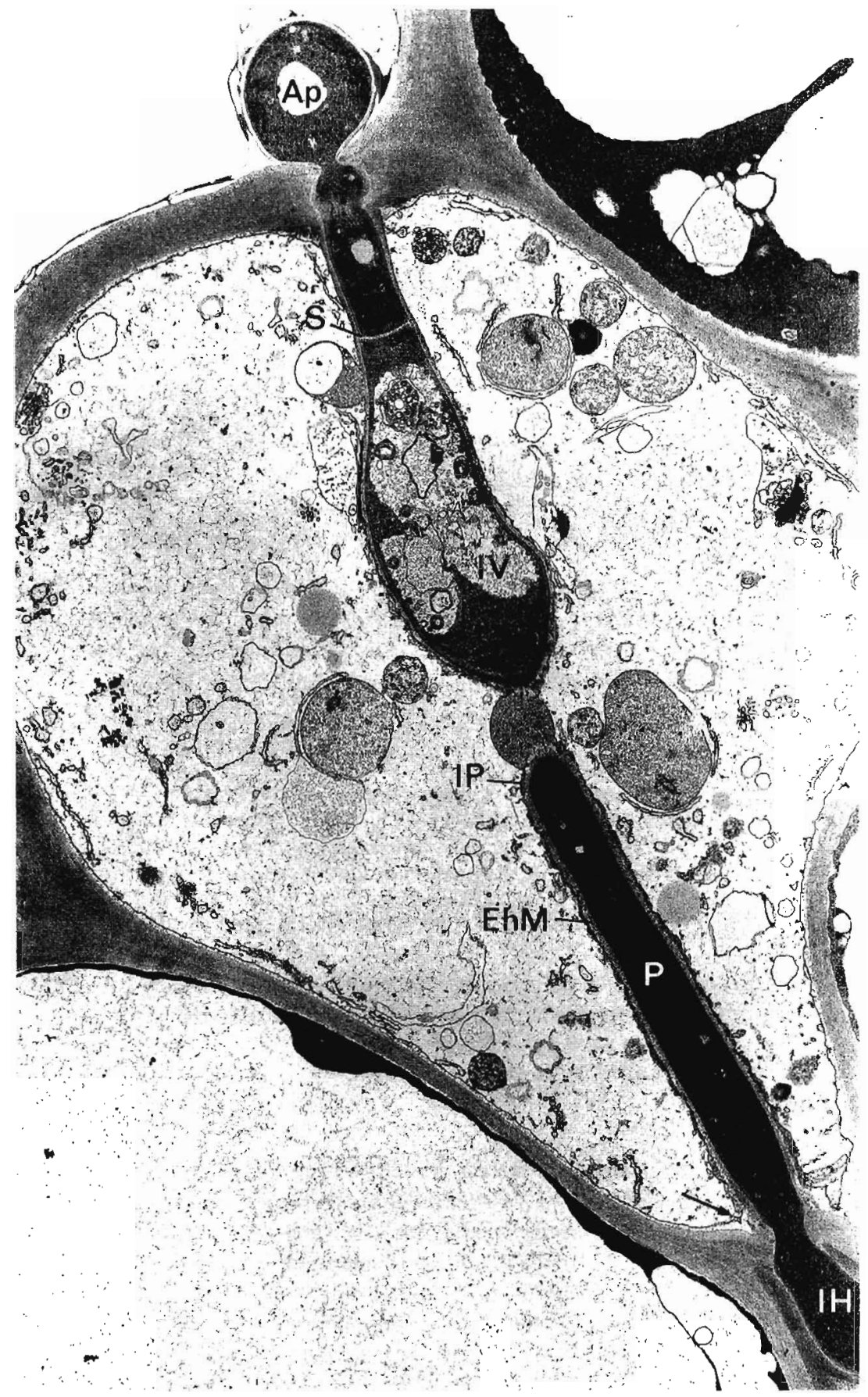

Figure 43. Direct penetration from appressorium (Ap) of Cronartium fusiforme in hypocotyl of loblolly pine The vacuolated intraepidermal vesicle (IV) and primary hypha (P) are bordered by the invaginated plasmalemma (IP) and a prominent extrahyphal matrix (EhM). The IP is fused with noninvaginated plasmalemma (arrow) where $P$ exits the epidermal cell to become an intercellular hypha $(\mathrm{IH})$. Note septate $(\mathrm{S})$ neck region of the vesicle. (7160x.) (From Gray et al., 1983.) 


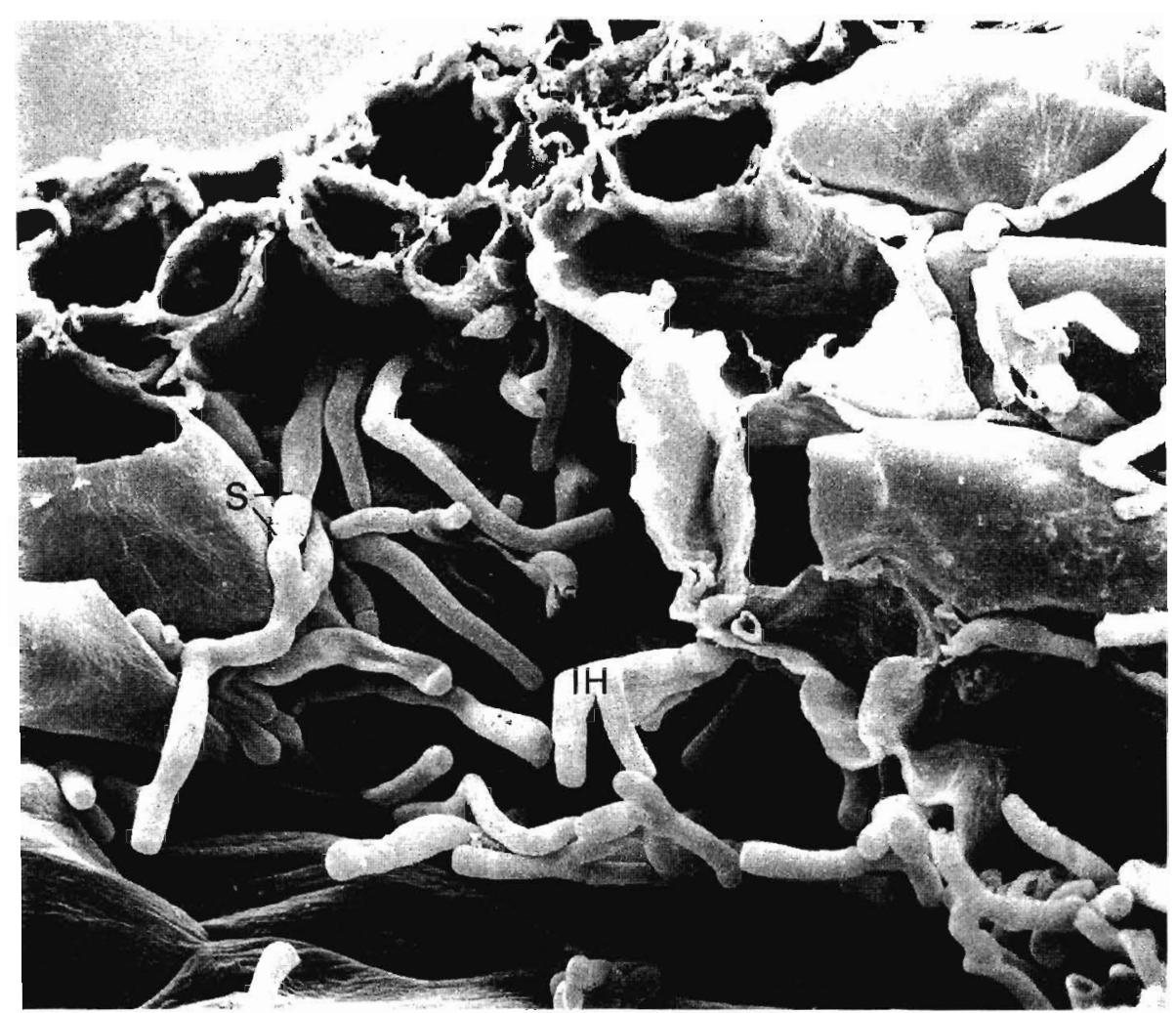

Figure 44. Intercellular hyphae (IH) of Chrysomyxa abietis in spruce needle. Noce clearly visible septa (S). (1000×.) (From Grill et al., 1980; Courtesy of Center for Electron Microscopy, University of Graz, Austria.) 


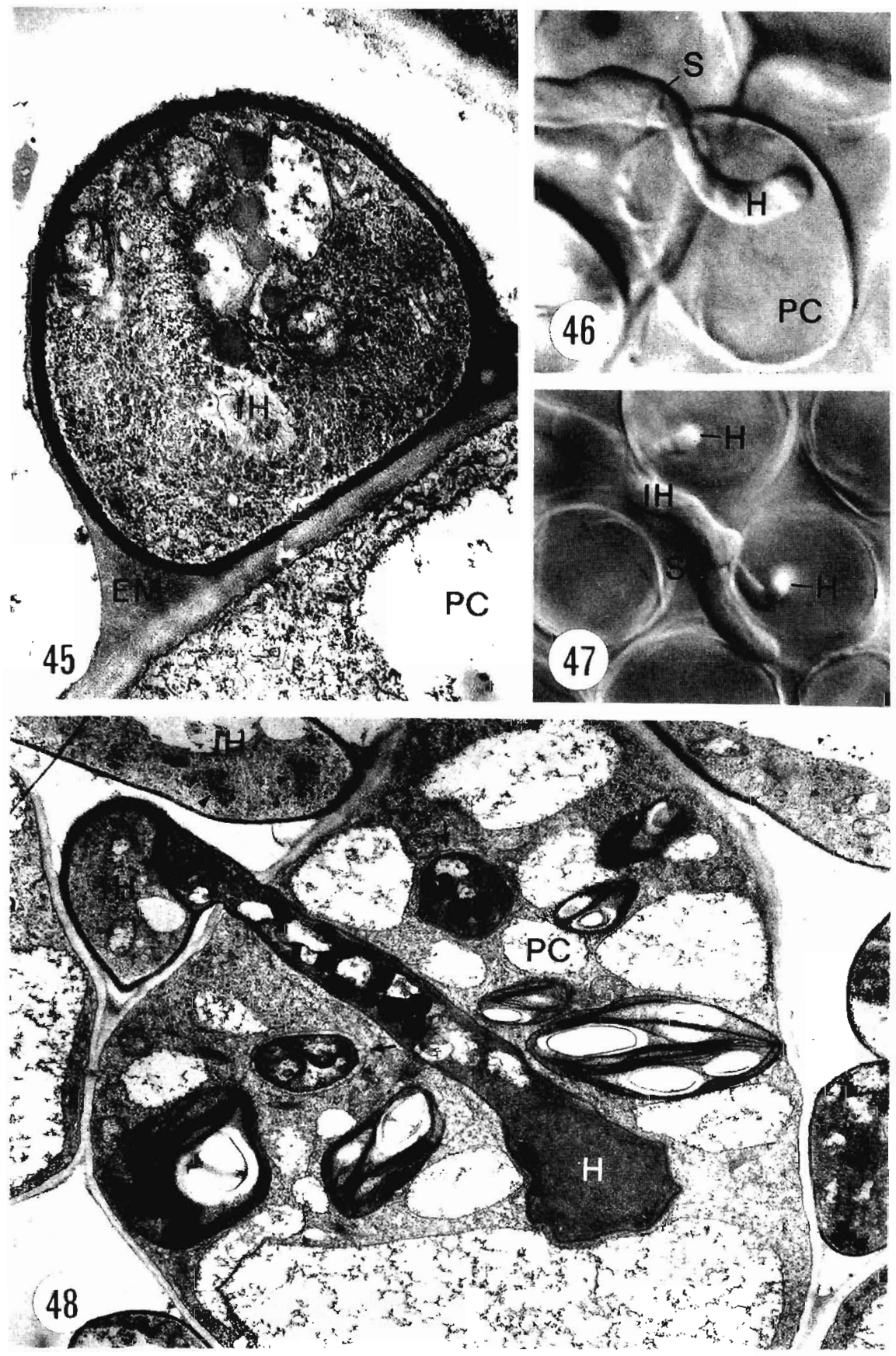

Figures 45-48. Inter- $(\mathrm{IH})$ and intracellular hyphae $(\mathrm{H})$ of Uromyces appendicularus in bean leaf tissue. (From Gold and Mendgen, 1984b.) Figure 45. IH in cross section showing extracellular matrix (EM) along its periphery and at points of contact with host cell. L, lipid body; PC, parenchyma cell. (21,260×.) Figure 46. Terminal, fingerlike H. Note septum (S) prior to penetration site of parenchyma cell (PC). (1180×.) Figure 47. IH with two $\mathrm{H}$ that formed as side branches. Note septa (S) near penetration sites $(980 \times$.) Figure 48 . Median longitudinal section through a penetration site into a parenchyma cell (PC). The invaginated plasma membrane and extrahyphal matrix are only clearly visible surrounding adjacent cross-sectioned $\mathrm{H}$ (arrows). Patches of glycogenlike particles (arrowheads) are seen in the IH. (6210x.) 

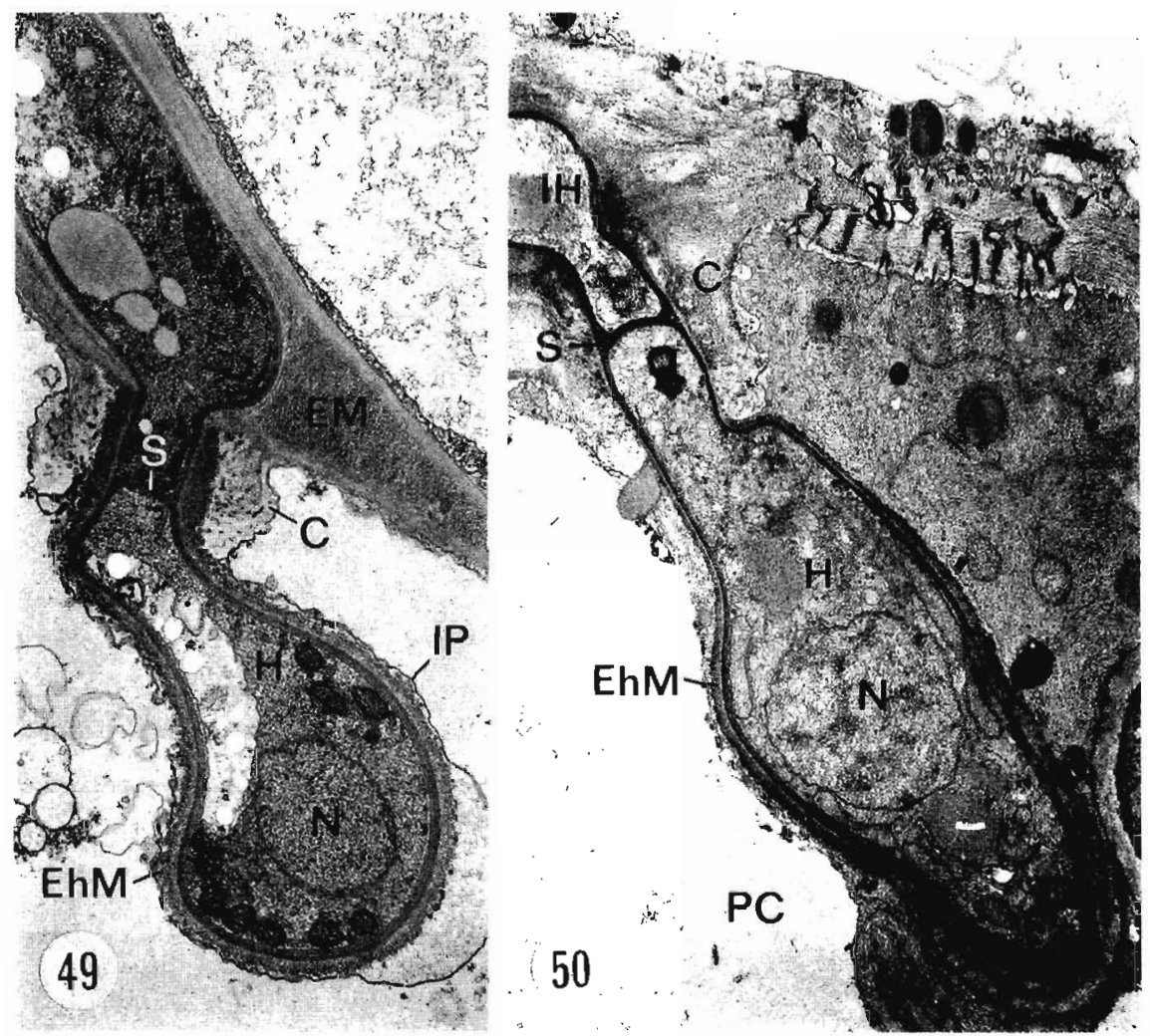

Figure 49. Intracellular hypha $(\mathrm{H})$ of Cronartium fusiforme in loblolly pine cell with associated extrahyphal matrix (EhM) and invaginated host plasmalemma (IP). A well-developed collar (C) containing membranous components surrounds the neck region of the H. The EhM appears similar to the extracellular matrix (EM) surrounding the intercellular hyphae (IH). N, nucleus; S, septum. ( $9960 \times$.) (From Gray et al., 1982.)

Figure 50. Intracellular hypha (H) of Peridermium pini in a pine parenchyma cell (PC). Note the collarlike wall apposition (C) and the septum (S). The intercellular hypha (IH) is only slightly constricted at the penetration site. N, nucleus; EhM, extrahyphal matrix. $(10,000 \times$.) (From Walles, 1974.) 


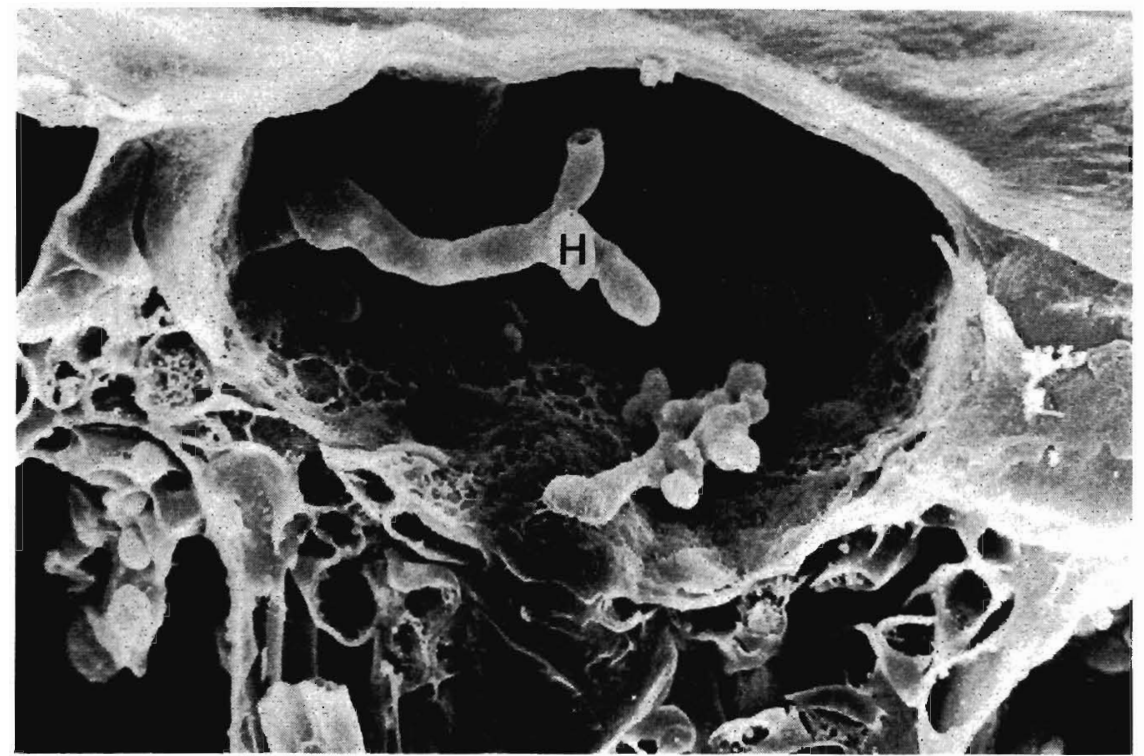

Figure 51. Two intracellular hyphae $(\mathrm{H})$ of Puccinia recondita in epidermal cell of Thalictrum speciosissimum. Note the branched, hyphalike morphology of the H. (1900×.) (From Gold et al., 1979.)
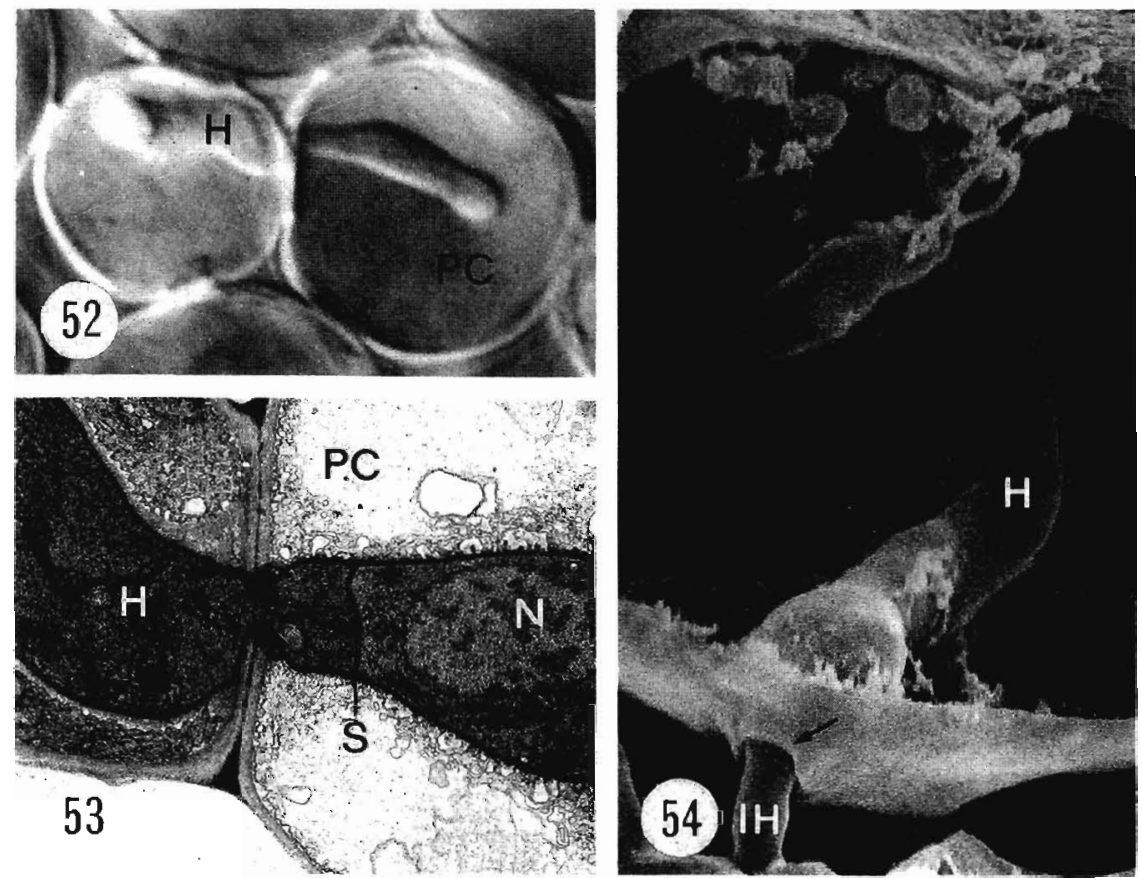

Figures 52-54. Transcellular penetration sites. Figure 52. Intracellular hypha (H) of Uromyces appendiculatus between two parenchyma cells (PC). (1590×.) (From Gold and Mendgen, 1984b.) Figure 53. Intracellular hypha (H) of Gymnosporangium fuscum in pear parenchyma cells (PC) with septum (S) prior to penetration site. N, nucleus. $(8000 \times$.) (Courtesy of B. Metzler, unpublished.) Figure 54. Coiled intracellular hypha (H) of Puccinia malvacearum in parenchyma cell of hollyhock. Note the branched. hyphalike nature of the $\mathrm{H}$ and exit from the host cell (arrow) to become an intercellular hypha $(\mathrm{IH}) .(5400 \times$.) (From R. E. Gold and L. J. Littlefield, unpublished.) 

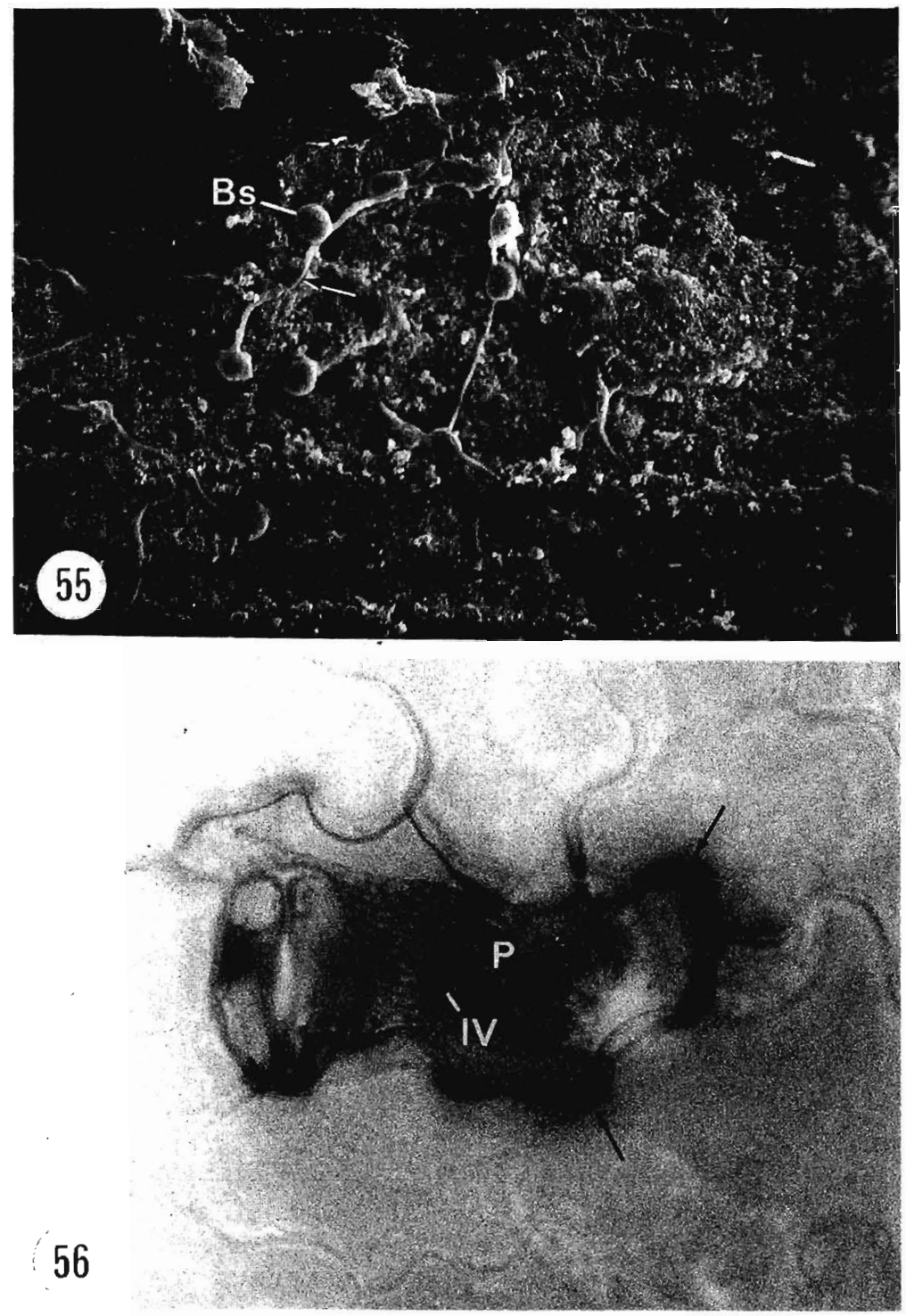

Figure 55. Basidiospore germlings (Bs) of Cronartium ribicola on a leaf of a resistant pine cultivar. The germ tubes grew randomly across the wax-covered epidermis without attempting to penetrate the wax-occluded stomatal antechamber (arrow). (500×.) (Courtesy of R. F. Patton, unpublished.)

Figure 56. Attempted penetration by basidiospore germling of Uromyces vignae on the nonhost Vicia faba. The germling was removed during processing for light microscopy. The incompatible host-parasite interaction resulted in necrosis of the epidermal cell; note rippled appearance of the epidermis and darker-stained anticlinal walls (arrows). The necrotic intraepidermal vesicle (IV) and primary hypha (P) are visible. $(500 \times$.) (Courtesy of S. Freytag, unpublished.) 

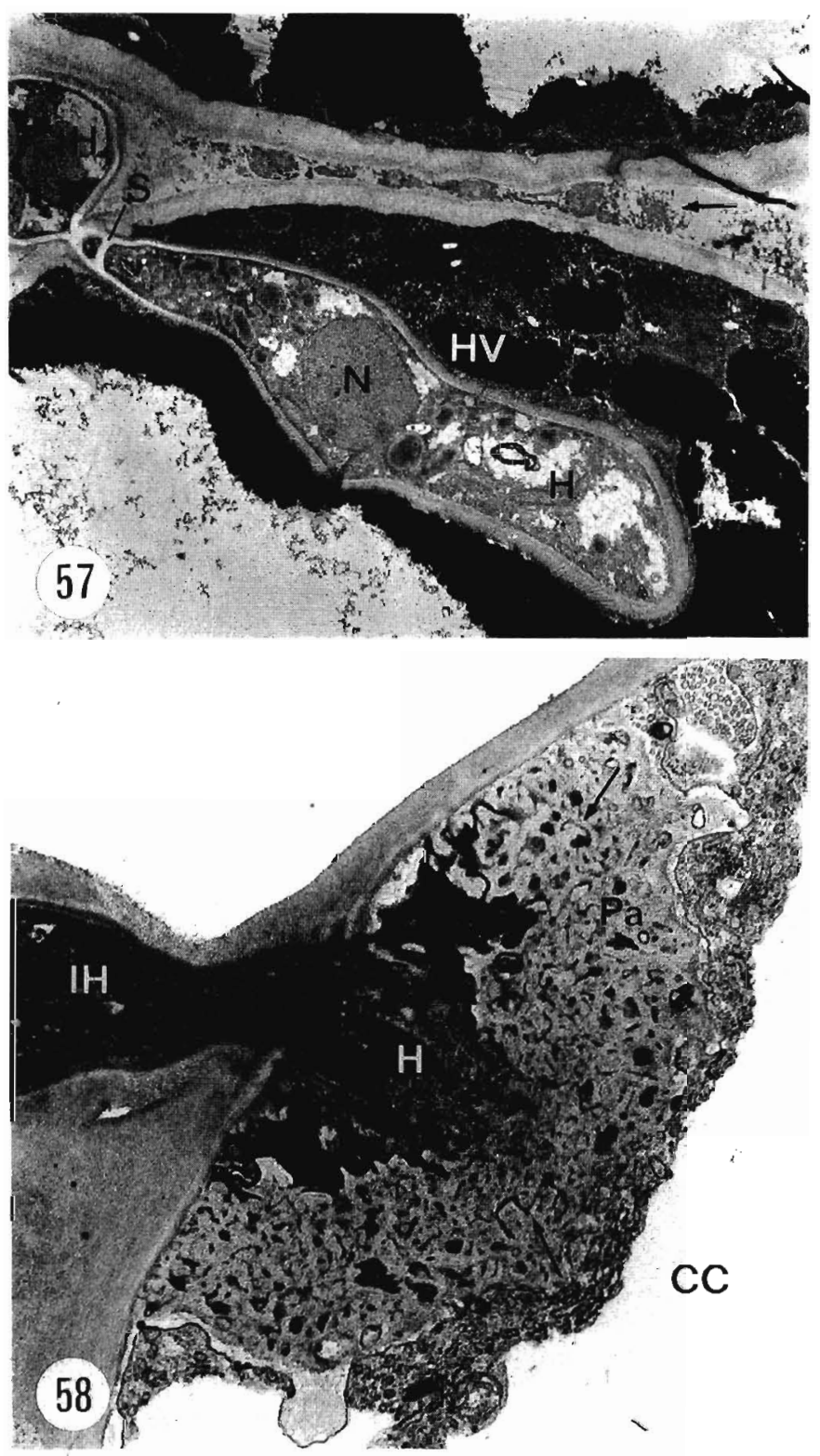

Figure 57. Longitudinal section through a disorganized intracellular hypha $(\mathrm{H})$ of Cronartium ribicola in an axenic-cultured pine cell. The $\mathrm{H}$ is surrounded by host vacuoles (HV) that contain densely staining tannin deposits and the intercellular space is filled with cellular debris (arrow). IH, intercellular hypha; N, nucleus; S, septum. (4320x.) (From Robb et al., 1975.)

Figure 58. An aborted intracellular hypha $(\mathrm{H})$ of Cronartium fusiforme in a cortical cell (CC) of a resistant loblolly pine seed line. A large papillar wall apposition $(\mathrm{Pa})$ formed in response to attempted penetration. Note the heterogeneous appearance of the $\mathrm{Pa}$ and abundance of electron-dense membranous material (arrows) in the apposition and in the adjacent host cytoplasm. The intercellular hypha (IH) is also necrotic. $(12,000 \times$.) (From Gray and Amerson, 1983.) 
Acknowledgments. We thank L. Bruscaglioni, S. Freytag, B. Metzler, and R. F. Patton for use of their unpublished micrographs and S. Freytag for putting together her unpublished data in Fig. 20. We thank C. W. Mims and E. A. Richardson for use of their micrographs prior to publication and colleagues who provided prints or negatives of their previously published cytological results. We thank A. Akers and J. B. Speakman for critical reading of the manuscript; especially for their suggestions and discussions. Finally, we gratefully acknowledge H. Fendrich (Universität Konstanz) for preparation of the graphics and the BASF AG for technical support in the photographic laboratory and word processing.

Note added in proof: Since this chapter was written, experiments with basidiospores of $M$. pinitorqua on shoots of $P$. sylvestris have provided information on the effect of the epicuticular wax structure on pre-penetration development of germlings (Desprez-Loustau and Le Menn, 1989). Also, two reports on host response to basidiospore infections have appeared (Heath, 1989; Hopkins and Reid, 1988).

\section{REFERENCES}

A]-Khesraji, T. O., and Lösel, D. M., 1981, The fine structure of haustoria, intracellular hyphae and intercellular hyphae of Puccinia poarum, Physiol. Plänt Pathol. 19:301-311.

Allen, R. F, 1930, A cytological study of heterothallism in Puccinia graminis, J. Agric. Res. 40:585-614.

Allen, R. F, 1932, A cytological study of heterothallism in Puccinia coronata, J. Agric. Res. 45:513-541.

Allen, R. F., 1933, A cytological study of the teliospores, promycelia, and sporidia in Puccinia malvacearum, Phytopathology 23:572-586.

Allen, R. F., 1934, A cytological study of heterothallism in flax rust, J. Agric. Res. 49:765-791.

Allen, R. F., 1935, A cytological study of Puccinia malvacearum from the sporidium to the teliospore, J. Agric. Res. 51:801-818.

Anikster, Y., 1983, Binucleate basidiospores--A general rule in rust fungi, Trans. Br. Mycol. Soc. 81:624-626.

Anikster, Y., and Wahl, I., 1985, Basidiospore formation and self-fertility in Puccinia mesnieriana, Trans. Br. Mycal. Soc. 84:164-167

Anikster, Y., Moseman, J. G., and Wahl, I., 1980, Development of basidia and basidiospores in Uromyces species on wild barley and Liliaceae in Israel, Trans, Br. Mycol. Soc. 75:377-382.

Ashworth, D., 1931, Puccinia malvacearum in monosporidial culture, Trans. Br. Mycol. Soc. 16:177-202.

Ashworth, D., 1935, An experimental and cytological study of the life history of Endophyllum sempervivi, Trans. Br. Mycol. Soc. 19:240-258.

Bauer, R., 1986, Basidiosporenentwicklung und -keimung bei Heterobasidiomyceten. Teil A: Experimentellontogenetische und karyologische Untersuchungen an keimenden Rostpilzbasidiosporen, Ber. Disch. Bot. Ges 99:67-81.

Bauer, R., 1987, Uredinales--germination of basidiospores and pycnospores, Stud. Mycol. 30:111-125.

Bauer, R., and Oberwinkler, F., 1988, Nuclear degeneration during ballistospore formation of Cronartium asclepiadeum (Uredinales), Bot. Acta 101:272-282.

Bega, R. V., 1960, The effect of environment on germination of sporidia in Cronartium ribicola, Phytopathology 50:61-69.

Blank, L. M., and Leathers, C. R., 1963, Environmental and other factors influencing development of southwestern cotton rust (Puccinia stakmanii), Phytopathology 53:921-928.

Borland, J., and Mims, C. W., 1980, An ultrastructural comparison of the aecial and telial haustoria of the autoecious rust Puccinia podophylli, Mycologia 72:767-774.

Bushnell, W. R., and Roelfs, A. P. (eds.), 1984, The Cereal Rusts, Volume I, Academic Press, New York.

Chong, J., Harder, D. E., and Rohringer, R., 1981, Ontogeny of mono- and dikaryotic rust haustoria: cytochemical and ultrastructural studies, Phytopathology 71:975-983.

Colley, R. H., 1918, Parasitism, morphology, and cytology of Cronartium ribicola, J. Agric. Res. 15:619-660

Cotter, R. U., 1932, Factors affecting the development of the aecial stage of Puccinia graminis, U. S. Dep. Agric. Tech. Bull. 314:1-37

Cutler, D. F, Alvin, K. L., and Price, C. E. (eds.), 1982, The Plant Cuticle, Academic Press, New York.

de Bary, A., 1863, Recherches sur le développement de quelches champignons parasites, Ann. Sci. Nat. Bot. 20 $5-148$. 
de Bary, A., 1865, Neue Untersuchungen über die Uredineen, insbesondere die Entwicklung der Puccinia graminis und den Zusammenhang derselben mit Aecidium berberidis, Monatsber. K. Akad. Wiss, Berlin 1865:15-50.

de Bary, A., 1866, Neue Untersuchungen über Uredineen, Monatsber. K. Akad. Wiss. Berlin 1866:205-215.

de Bary, A., 1884, Vergleichende Morphologie und Biologie der Pilze Mycetozoen und Bakterien, Engelmann, Leipzig.

Desprez-Loustau, M.-L., 1986, Physiologie in vitro des basidiospores de Melampsora pinitorqua: conséquences pour la compréhension des infections, Eur. J. For. Pathol. 16:193-206.

Desprez-Loustau, M.-L. and Le Menn, R., 1989, Epicuticular waxes and Melampsora pinitorqua Rostr. preinfection behaviour on maritime pine shoots, Eur. J. For. Pathol. 19:178-188.

Diner, A. M., and Mott, R. L., 1982a, Axenic cultures from basidiospores of Cronartium ribicola, Can. J. Bot. 60:1950-1955.

Diner, A. M., and Mott, R. L., 1982b, A rapid axenic assay for hypersensitive resistance of Pinus lambertiana to Cronartium ribicola, Phytopathology 72:864-865.

Diner, A. M., and Mott, R. L., 1982c, Direct inoculation of five-needle pines with Cronartium ribicola in axenic culture, Phylopathology 72:1181-1184.

Eriksson, J., 1911, Der Malvenrost (Puccinia malvacearum Mont.), seine Verbreitung, Natur und Entwicklungsgeschichte, K. Sven. Vetenskapsakad. Handl. 47:1-125.

Fischer, E., 1898, Entwicklungsgeschichtliche Untersuchungen über Rostpilze, Beitr. Kryptogamenflora Schweiz 1:I-121.

Fischer, E., 1901, Aecidium elatinum Alb. et Schw. der Urheber des Weisstannen-Hexenbesens und seine Uredound Teleutosporenform, Z. Pfanzenkr. 11:321-343.

Freytag, S., Bruscaglioni, L., Gold, R. E., and Mendgen, K., 1988, Basidiospores of rust fungi (Uromyces species) differentiate infection structures in vitro, Exp. Mycol. 12:275-283

Gasparrini, G., 1848, Osservazioni sulla generazione delle spore nel Podisoma fuscum, Rend. R. Accad. Sci. Napoli 7:346-356.

Gold, R. E., and Littlefield, L. J., 1979, Light and scanning electron microscopy of the telial, pycnial, and aecial stages of Melampsora lini, Can. J. Bot. 57:629-638.

Gold, R. E., and Mendgen, K., 1983, Activation of teliospore germination in Uromyces appediculatus var. appendiculatus. II. Light and host volatiles, Phytopathol. Z. 108:281-293.

Gold, R. E., and Mendgen, K., 1984a, Cytology of basidiospore germination, penetration, and early colonization of Phaseolus vulgaris by Uromyces appendiculatus var. appendiculatus, Can. J. Bot . 62:1989-2002.

Gold, R. E., and Mendgen, K., 1984b, Vegetative development of Uromyces appendiculatus var. appendiculatus in Phaseolus vulgaris, Can. J. Bot. 62:2003-2010.

Gold, R. E., and Mendgen, K., 1984c, Cytology of teliospore germination and basidiospore formation in Uromyces appendiculatus var. appendiculatus, Protoplasma 119:150-155.

Gold, R. E., Littlefield, L. J. and Statler, G. D., 1979, Ultrastructure of the pycnial and aecial stages of Puccinia recondita, Can. J. Bot. 57:74-86.

Gopinathan Nair, K. R., 1972, A unique mode of multiplication of basidiospores in Ravenelia hobsoni (Uredinales). Experientia 28:604-605.

Gould, C. J., and Shaw, C. G., 1969, Spore germination in Chyrsomyxa spp., Mycologia 61:694-717.

Gray, D. J., and Amerson, H. V., 1983, In vitro resistance of embryos of Pinus taeda to Cronartium quercuum f. sp. fusiforme: Ultrastructure and histology, Phytopathology 73:1492-1499.

Gray, D. J., Amerson, H. V., and Van Dyke, C. G., 1982, An ultrastructural comparison of monokaryotic and dikaryotic haustoria formed by the fusiform rust fungus Cronartium quercuum $\mathrm{f}$. sp. fusiforme, Can. J. Bot. 60:2914-2922.

Gray, D. J., Amerson, H. V., and Van Dyke, C. G., 1983, Ultrastructure of the infection and early colonization of Pinus taeda by Cronartium quercuum formae speciales fusiforme, Mycologia 75:117-130.

Grill, D., Hafellner, J., and Waltinger, H., 1980, Rasterelektronenmikroskopische Untersuchungen an Chrysomyxa abietis befallenen Fichtennadeln, Phyton 20:279-284.

Hansen, E. M., and Patton, R. F., 1975, Types of germination and differentiation of vesicles by basidiospores of Cronartium ribicola, Phytopathology 65:1061-1071.

Hansen, E. M., and Patton, R. F., 1977, Factors important in artificial inoculation of Pinus strobus with Cronartium ribicola, Phytopathology 67:1108-1112.

Harder, D. E., 1978, Comparative ultrastructure of the haustoria in uredial and pycnial infections of Puccinia coronata avenae, Can. J. Bot. 56:214-224.

Harder, D. E., and Chong, J., 1984, Structure and physiology of haustoria, in: The Cereal Rusts, Volume I (W. R. Bushnell and A. P. Roelfs, eds.), Academic Press, New York, pp. 431-476. 
Heath, M. C.. 1989. A comparison of fungal growth and plant responses in cowpea and bean cultivars inoculated with urediospores or basidiospores of the cowpea rust fungus, Physiol. Molec. Plan Pathol. 34:415-426.

Hoffman. A. W. H., 1912, Zur Entwicklungsgeschichte von Endophyllum sempervivi, Centralbl. Bakteriol. Abi. II 32:137-158.

Hopkin, A. A., and Reid, J., 1988, Cytological studies of the M-haustorium of Endocronartium harknessii: Morphology and ontogeny, Can. J. Bor. 66:974-988.

Hopkin, A. A., and Reid, J., 1988. Host cell responses in susceptible hard pine tissue infected with Endocronartium harknessii, Can. J. Bot. 66:2511-2517.

Jacobi, W. R., Amerson, H. V., and Motr, R. L., 1982, Microscopy of cultured loblolly pine seedlings and callus inoculated with Cronartium fusiforme, Phyoparhology 72:138-143.

Jonsson, A., Holmvall, M., and Walles, B., 1978, Uhrastructural studies of resistance mechanisms in Pinus sylvesıris L. against Melampsora pinitorqua (Braun) Rostr. (pine Iwisting rust). Stud. For. Suec 145:1-28.

Kapooria, R. G., 1968, Cytological studies of the germinating teliospores and basidiospores of Puccinia penniseri, Neth. J. Plant Puthol. 74:2-7.

Kapooria, R. G., 1971, A cytological study of promycelia and basidiospores and the chromosome number in Uromyces fabae, Neth. J. Plani Puthol. 77:91-96.

Kapooria, R. G., and Zadoks, J. C., 1973, Morphology and cytology of the promycelium and the basidiospore of Puccinia horiana, Neth. J. Plant Pathol. 79:236-242.

Kinloch, B. B., Jr., and Littlefield, J. L., 1977, White pine blister rust: Hypersensitive resistance in sugar pine, Can. J. Bot. 55:1148-1155.

Knauf, G., and Mendgen, K., 1988, Secretion systems and membrane associated structures in rust fungi after high pressure freezing and freeze fracturing, Biol. Cell 64:35I-358.

Koch, E., and Hoppe, H. H., 1988, Development of infection structures by the direct-penetrating soybean rust fungus (Phakopsora pachyrhizi Syd.) on artificial membranes, J. Phyroparhol. (Berlin) 122:232-244.

Kohno, M., Nishimura, T., Ishizaki, H., and Kunoh, H., 1975, Cytological studies on rust fungi. (III) Nuclear behaviors during the process from teliospore stage through sporidial stage in two short-cycled rusts, Kuchneola japonica and Puccinia horiana, Bull. Fac. Agric. Mie Univ. 49:21-29.

Kohno, M., Ishizaki, H., and Kunoh, H., 1977a, Cytological studies on rust fungi. (VI) Fine structures of infection process of Kuehneola japonica (Diet.) Dietel, Mycopathologia 61:35-41.

Kohno. M., Nishimura, T., Noda, M., Ishizaki, H., and Kunoh, H., 1977b, Cylological studies on rust fungi. (VII) The nuclear behavior of Gymnosporangium asiaricum, Miyabe et Yamada during the stages from teliospore germination through sporidium germination, Trans. Mycol. Soc. Jpn. 18:211-219.

Krebill, R. G., 1972, Germination of basidiospores of Cronartium comandrae on rocks and vegetation, Phyropathology 62:389-390.

Kuhlmann, E. G., 1988, Histology and progression of fusiform rust symptoms on inoculated loblolly pine seedlings, Plant Dis. 72:719-721.

Lindfors, T., 1924, Studien über den Entwicklungsverlauf bei einigen Rostpilzen aus zytologischen und anatomischen Gesichtspunkten, Sven. Bor. Tidskr. 18:1-84.

Littlefield, L. J., and Heath, M. C., 1979, Ultrastructure of Rust Fungi. Academic Press, New York.

Longo, N., and Naldini Longo, B., 1982, Behaviour of the monokaryotic haustorium of Melampsora pinirorqua (A.Br.) Rostr. Preliminary note, Caryologia 35:471-476.

Longo, N., Moriondo, F, and Naldini Longo, B., 1982, Ultrastructural observations on the host-pathogen interface in infections of Cronartium flaccidum on pine, Caryologia 35:307-326.

MacLachlan, J. D., 1935, The dispersal of viable basidiospores of the Gymnosporangium rusts, J. Arnold Arbor. Harv. Univ. 16:411-422.

Melander, L. W., and Craigie, J. H., 1927, Nature of resistance of Berberis spp. to Puccinia graminis, Phyroparholog: 17:95-114.

Melhus, I. E., Durrell, L. W., and Kirby, R. S. 1920, Relation of the barberry to stem rust in lowa, Iowa Agric. Exp. Sin. Res. Bull. 57:283-325.

Mendgen, K., Lange, M., and Bretschneider, K., 1985, Quantitative estimation of the surface carbohydrates on the infection structures of rust fungi with enzymes and lectins. Arch. Microbiol. 140:307-311.

Mendgen, K., 1973, Microbodies (glyoxysomes) in infection structures of Uromyces phaseoli, Protoplasma 78:477-482.

Mendgen, K.. 1984, Development and physiology of teliospores, in: The Cereal Rusts, Volume I (W. R. Bushnell and A. P. Roelfs, eds.), Academic Press, New York, pp. 375-398.

Mendgen, K., Schneider, A., Sterk, M., and Fink, W, 1988, The differentiation of infection structures as a result of recognition events between some biotrophic parasites and their hosts, J. Phyroparhol. (Berlin) 123:259-272. 
Metzler, B., 1982, Untersuchungen an Heterobasidiomyceten (23): Basidiosporenkeimung und Infektionsvorgang beim Birnengitterrost, Phytopathol. Z. 103:126-138.

Miller, T., Patton, R. F, and Powers, H. R., Jr., 1980, Mode of infection and early colonization of slash pine seedlings by Cronartium quercuum f. sp. fusiforme, Phytopathology 70:1206-1208.

Mims, C. W., 1977, Fine structure of basidiospores of the cedar-apple rust fungus Gymnosporangium juniperivirginianae, Can. J. Bot. 55:1057-1063.

Mims, C. W., and Richardson, E. A., 1989, Ultrastructure of appressorium development by basidiospore germlings of the rust fungus Gymnosporangium juniperi-virginianae, Protoplasma 148:11]-119.

Mims, C. W., Roberson, R. W., and Richardson, E. A., 1988, Ultrastructure of freeze-substituted and chemically fixed basidiospores of Gymnosporangium juniperi-virginianae, Mycologia 80:356-364.

Nusbaum, C. J., 1935, A cytological study of the resistance of apple varieties to Gymnosporangium juniperivirginianae, J. Agric. Res. 51:573-596.

Olive, L. S., 1949, A cytological study of typical and atypical basidial development in Gymnosporangium clavipes, Mycologia 41:420-426.

Pady, S. M., 1935, The role of intracellular mycelium in systemic infections of Rubus with the orange-rust, Mycologia 27:618-637.

Patton, R. F, and Johnson, D. W., 1970, Mode of penetration of needles of eastern white pine by Cronartium ribicola, Phytopathology 60:977-982.

Patton, R. F., and Spear, R. N., 1980, Stomatal influences on white pine blister rust infection, Phytopathol. Mediterr. 19:1-7.

Petersen, R. H., 1974, The rust fungus life cycle, Bot. Rev. 40:453-513.

Poirault, G., and Raciborski, M., 1895, Sur les noyaux des Urédinées, J. Bot. 9:381-388.

Ragazzi, A., and Dellavalle Fedi, I., 1982, Observations under fluorescence on progress of basidiospore germination in Cronartium flaccidum (Alb. et Schw.) Wint. on the needle surface of certain pine species, Eur. J. For. Paihol. 12:246-251.

Ragazzi, A., Dellavalle Fedi, I., and Mesturino, L., 1986, Cronartium flaccidum (Alb. et Schw.) Wint. spores: Temperature requirements for germination, Phytopathol. Mediterr. 25:57-60.

Ragazzi, A., Fagnani, A., Dellavalle Fedi, 1., and Mesturino, L., 1987, Pinus pinaster e Pinus sylvestris: due specie a diverso comportamento verso Cronartium flaccidum, Phytopathol. Mediterr. 26:81-84.

Ráthay, E., 1881, Über das Eindringen der Sporidien-Keimschläuche der Puccinia malvacearum Mont. in die Epidermiszellen der Althaea rosea, Verh. Zool. Bot. Ges. Wien 31:9-10.

Reed, H. S., and Crabill, C. H., 1915, The cedar rust disease of apples caused by Gymnosporangium juniperivirginianae Schw., Va. Agric. Exp. Stn. Tech. Bull. 9:1-106.

Reess, M., 1865, Chrysomyxa abietis Unger und die von ihr verursachte Fichtennadelnkrankheit, Bot. Ztg. 23: 385-388.

Reess, M., 1870, Die Rostpilzformen der deutschen Coniferen, Abh. Naturforsch. Ges. Halle 11:50-118.

Rijkenberg, F. H. J., and Truter, S. J., 1972, Haustoria and intracellular hyphae in the rusts, Phytopathology 62 : 281-286.

Robb, J., Harvey, A. E., and Shaw, M., 1975, Ultrastructure of tissue cultures of Pinus monticola infected by Cronartium ribicola. II. Penetration and post-penetration, Physiol. Plant Pathol. 5:9-18.

Robinson, W., 1914, Some experiments on the effect of external stimuli on the sporidia of Puccinia malvacearum (Mont.), Ann. Bot. (London) 28:331-340.

Roncadori, R. W. 1968, The pathogenicity of secondary and tertiary basidiospores of Cronartium fusiforme, Phytopathology 58:712-713.

Sappin-Trouffy, P., 1896, Recherches histologiques sur les Urédinées, Botaniste 5:59-244.

Savile, D. B. O., 1939, Nuclear structure and behavior in species of the Uredinales, Am. J. Bot. 26:585-609.

Siggers, P. V., 1947, Temperature requirements for germination of spores of Cronartium fusiforme, Phytopathology 37:855-864.

Snow, G. A., 1968a, Basidiospore production by Cronartium fusiforme as affected by suboptimal temperatures and preconditioning of teliospores, Phytopathology 58:1541-1546.

Snow, G. A., 1968b, Time required for infection of pine by Cronartium fusiforme and effect of field and laboratory exposure after inoculation, Phytopathology 58:1547-1550.

Snow, G. A., and Froelich, R. C., 1968, Daily and seasonal dispersal of basidiospores of Cronartium fusiforme, Phytopathology 58:1532-1536.

Spaulding, P., and Rathbun-Gravatt, A., 1926, The influence of physical factors on the viability of sporidia of Cronartium ribicola Fischer, J. Agric. Res. 33:397-433.

Thirumalachar, M. J., 1939, Rust on Jasmium grandiflorum, Phytopathology 29:783-792. 
Thirumalachar, M. J., 1945, Development of spore-forms and the nuclear cycle in the autoecious opsis rust, Cystopsora oleae, Bot. Gaz. (Chicago) 107:74-86.

Tulasne, L. R., 1854, Second mémoire sur les Urédinées et les Ustilagineées, Ann. Sci. Nat. Bot. 4 Ser. 2:77-196.

Van Sickle, G. A., 1975, Basidiospore production and infection of balsam fir by a needle rust, Pucciniastrum goeppertianum, Can. J. Bor. 53:8-17.

Walkinshaw, C. H., 1978, Cell necrosis and fungus content in fusiform rust-infected loblolly, longleaf, and slash pine seedlings, Phytopathology 68:1705-1710.

Walles, B., 1974, Ultrastructure of the rust fungus Peridermium pini (Pers.) Lev., Stud. For. Suec. 122:1-30.

Waterhouse, W. L., 1921, Studies in the physiology of parasitism. VII. Infection of Berberis vulgaris by sporidia of Puccinia graminis, Ann. Bot. (London) 35:557-564.

Weimer, J. L., 1917. Three cedar rust fungi, their life histories and diseases they produce, Cornell Univ. Agric. Exp. Sin. Bull. 390:507-549.

Welter, K., Müller, M., Mendgen, K., 1988, The hyphae of Uromyces appendiculatus within the leaf tissue after high pressure freezing and freeze substitution, Protoplasma 147:9l-99.

Woods, A. M., and Gay, J. L., 1987, The interface between haustoria of Puccinia poarum (monokaryon) and Tussilago farfara, Physiol. Mol. Plant Pathol. 30:167-185.

Yamada, S., 1956, Experiments on the epidemiology and control of Chrysanthemum white rust, caused by Puccinia horiama P. Henn., Ann. Phytopathol. Soc. Japan 20:148-154.

Zeyen, R. J., and Bushnell, W. R., 1981, An in-block, light microscope viewing procedure for botanical materials in plastic embedments; with emphasis on location and selection of host cell-microbe encounter sites, $C a n . J$. Bot. 59:397-402. 